\title{
Fault inversion contributes to ground deformation above inflating igneous sills
}

\author{
James Norcliffe ${ }^{\alpha}$, Craig Magee ${ }^{\star}$, Christopher A-L Jackson ${ }^{\alpha}$, \\ Jonas Kopping $\gamma$, Bailey Lathrop ${ }^{\alpha}$ \\ ${ }^{\alpha}$ Basins Research Group (BRG), Department of Earth Science and Engineering, Imperial College London, London, SW7 2BP, UK. \\ $\beta$ School of Earth and Environment, University of Leeds, Leeds, LS2 9JT, UK. \\ $\gamma$ School of Earth, Atmosphere and Environment, Monash University, Melbourne, 3800, Australia.
}

\begin{abstract}
Space for magma is commonly generated by uplift of the overburden and free surface. If this deformation is elastic, we can invert the shape and kinematics of ground movement to model the geometry and dynamics of underlying intrusions. However, magma emplacement can be spatially accommodated by viscoelastic and/or plastic host rock deformation, although few studies have quantified the contributions of these processes. We restore ground deformation above a sill, imaged in 3D seismic reflection data, and show that: (i) where uplift equalled sill thickness, host rock bending accommodated intrusion; but (ii) where sill thickness exceeded uplift, normal fault inversion and overburden compaction generated space for intrusion. Our results support work showing intrusion-induced ground deformation may be restricted if multiple deformation processes accompany emplacement. We also demonstrate intrusion-induced uplift can drive fault inversion, meaning the present pattern of displacement on the faults surface may not reflect its tectonic growth history.
\end{abstract}

Keywords: Magma; Seismic reflection; Fold; Ground deformation; Australia

\section{InTRODUCTION}

Emplacement and inflation of sub-horizontal or inclined magma bodies (e.g. sills), particularly at shallow-levels, commonly causes uplift of the overlying rock and free surface [e.g. Biggs et al. 2011; Castro et al. 2016; Ebmeier et al. 2018; Galland 2012; Galland and Scheibert 2013; Hansen and Cartwright 2006; Johnson and Pollard 1973; Pollard and Johnson 1973; Schmiedel et al. 2017; Sigmundsson et al. 2020; Trude et al. 2003]. This overburden uplift generates space for, and thus accommodates, the intruded magma volume. If intrusion-induced uplift were to only involve linear elastic bending of the overburden, the shape and amplitude of the overlying fold produced (i.e. a 'forced fold') should broadly mimic the geometry and thickness of the underlying magma body [e.g. Bunger and Cruden 2011; Hansen and Cartwright 2006; Jackson et al. 2013; Pollard and Johnson 1973; Stearns 1978]. By assuming the host rock intruded by magma is elastic, we can analytically or numerically model ground deformation patterns recorded in active volcanic areas to infer intrusion geometries, locations, and dynamics [e.g. Biggs et al. 2009; Cannavò et al. 2015; Ebmeier et al. 2018; Pritchard and Simons 2004; Sigmundsson et al. 2020; Sparks et al. 2012; van Wyk de Vries et al. 2014]. However, numerous studies have demonstrated that host rock deformation can also involve viscoelastic and/or plastic (e.g. faulting or compaction) processes

${ }^{*}$ Corresponding author: c.magee@leeds.ac.uk [e.g. de Saint-Blanquat et al. 2006; Guldstrand et al. 2017; Jackson et al. 2013; Magee et al. 2013b; Magee et al. 2019a; Magee et al. 2017; Morgan et al. 2008; Poppe et al. 2019; Schmiedel et al. 2019; Schmiedel et al. 2017; Schofield et al. 2012; Sigmundsson et al. 2020; Wilson et al. 2016]. These viscoelastic and plastic processes can partly generate space for emplacement and thereby reduce the size of forced folds generated by uplift [e.g. Galland 2012; Jackson et al. 2013; Magee et al. 2013b; Magee et al. 2019a].

Although we recognise the need to better understand how magma emplacement translates into ground deformation [e.g. Ebmeier et al. 2018; Magee et al. 2018], most studies examine how intrusions create new structures (e.g. folds and faults) or modify host rock properties (e.g. porosity) [e.g. Hansen and Cartwright 2006; Magee et al. 2019a; Montanari et al. 2017; Morgan et al. 2008; Reeves et al. 2018]. Here, we use 3D seismic reflection data from offshore NW Australia to investigate how faults may affect the mechanics of roof uplift above an intruding sill. With these data we also explore how intrusion-induced deformation may modify fault displacement patterns, cautioning the way we use such patterns to unravel fault kinematics in areas of colocated faulting and magmatism [e.g. Nicol et al. 1995; Nicol et al. 1996; Rotevatn et al. 2019; Walsh and Watterson 1988]. We show that emplacement of the sill in the hanging wall of a major tectonic fault, at a depth of $\sim 0.9 \mathrm{~km}$ during the Late Jurassic, was primarily accommodated by roof uplift facilitated by folding and fault 
inversion. Local discrepancies between sill thickness and fold amplitude suggest other viscoelastic and/or plastic processes (e.g. porosity reduction) may have helped generate space for the intruding magma. We also demonstrate that fault inversion locally reduced throw (and displacement) across the fault, meaning the present pattern of displacement pattern on the faults surface does not record its nucleation and (extensional) growth history. For example, if not recognised as being intrusion-induced, the localised reductions in throw and/or displacement may be incorrectly interpreted as evidence of linkage between initially isolated normal fault segments [cf. Cartwright et al. 1995; Peacock and Sanderson 1991]. Overall, our work demonstrates that seismic reflection data is a powerful tool for unravelling how intruding magma is expressed at the surface and interacts with faults.

\section{Geological setting}

The North Carnarvon Basin, located offshore NW Australia (Figure 1A), formed through several phases of rifting between Australia and Greater India during the Late Carboniferous-to-Early Cretaceous [e.g. Direen et al. 2008; Gibbons et al. 2012; Longley et al. 2002; Stagg et al. 2004]. Our study area is located within the Exmouth Plateau, a region of the North Carnarvon Basin containing $<10 \mathrm{~km}$ thick, stretched continental crust and an up to $18 \mathrm{~km}$ thick sedimentary sequence (Figure 1) [e.g. Exon et al. 1992; Karner and Driscoll 1999; Pryer et al. 2002; Stagg et al. 2004]. To the north and west of the Exmouth Plateau are the Argo and Gascoyne abyssal plains, respectively, which consist of oceanic crust; between the Exmouth Plateau and the Gascoyne Abyssal Plain is a $200-250 \mathrm{~km}$ wide continent-ocean transition zone comprising heavily intruded continental crust (Figure 1A) [e.g. Direen et al. 2008; Symonds et al. 1998]. The Cuvier Abyssal Plain to the southwest, juxtaposed against the Exmouth Plateau by the Cape Range Fracture Zone, has traditionally been interpreted as oceanic crust, but may instead define a continent-ocean transition zone (Figure 1A) [see Reeve 2017, and references therein]. Several sub-basins (e.g. the Exmouth and Barrow sub-basins), each defined by a unique tectono-stratigraphic evolution, lie east of the Exmouth Plateau (Figure 1A) [e.g. Tindale et al. 1998].

The earliest phase of rifting on the Exmouth Plateau initiated in the Rhaetian (Late Triassic) and likely ceased towards the end of the Callovian (Middle Jurassic; Figure 1B) [e.g. Bilal et al. 2018; Black et al. 2017; Gartrell et al. 2016; Tindale et al. 1998]. Late Triassicto-Jurassic rifting produced an extensive array of $\sim \mathrm{N}-$ $\mathrm{S}$ striking, high-throw (up to $\sim 1 \mathrm{~km}$ ) normal faults, which offset a thick pre-rift succession primarily consisting of fluvio-deltaic sedimentary rocks (i.e. the Mungaroo Formation; Figure 1B, C, and 2A) [e.g. Bilal et al. 2018; Black et al. 2017; Marshall and Lang
2013; Stagg et al. 2004]. During the Early Jurassic, the Exmouth Plateau was sediment starved in comparison to the sub-basins located further east, resulting in deposition of a relatively condensed ( $\$ 100 \mathrm{~m}$ thick) latest Triassic-to-Early Jurassic, syn-rift succession (e.g. Figure 1C) [e.g. Exon et al. 1992; Karner and Driscoll 1999]. This syn-rift succession comprises the siliciclastic Brigadier and North Rankin formations, as well as the Murat Siltstone and Athol Formation, and records a transgression from shallow- to deeper-marine conditions (Figure 1B) [e.g. Hocking 1992; Hocking et al. 1987; Stagg et al. 2004; Tindale et al. 1998]. Development of a regional unconformity at the end of the Callovian marked the end of this first rift phase (Figure 1B) [e.g. Bilal et al. 2018; Yang and Elders 2016]. The unconformity is overlain by the marine Dingo Claystone (Oxfordian-to-Tithonian; Figure 1B) [e.g. Tindale et al. 1998].

Crustal extension is broadly considered to have continued throughout the Jurassic across the North Carnarvon Basin [e.g. Gartrell et al. 2016; Tindale et al. 1998], although the apparent cessation of faulting during deposition of the Dingo Claystone on the Exmouth Plateau suggests rifting may have been punctuated by a period of tectonic quiescence (Figure 1B) [e.g. Magee et al. 2015]. Development of the Base Cretaceous unconformity at $\sim 148 \mathrm{Ma}$ (latest Tithonian) and subsequent rapid subsidence, which allowed deposition of a thick succession of deltaic rocks (i.e. the Tithonian-toValanginian Barrow Group), mark the onset of a second rift phase across the Exmouth Plateau (Figure 1B, C) [e.g. Paumard et al. 2018; Reeve et al. 2016]. Tithonianto-Valanginian rifting involved relatively little upper crustal faulting, with this event producing an array of $\mathrm{N}-\mathrm{S}$ to NE-SW-striking, low-throw $(<0.1 \mathrm{~km})$ normal faults. It is thus likely that stretching during this period was dominated by depth-dependent extension or dynamic topography [e.g. Driscoll and Karner 1998; Reeve et al. 2016]. Rifting culminated in the development of a continent-ocean transition zone and ultimately continental break-up along the western margin of the Exmouth Plateau in the Valanginian-toHauterivian ( 135-130 Ma; Figure 1B) [e.g. Direen et al. 2008; Robb et al. 2005; Stagg et al. 2004]. Following continental break-up in the Early Cretaceous, thermal subsidence controlled margin development, resulting in the development of a thick post-rift succession, parts of which have been deformed by tiers of polygonal faults (e.g. Figure 1C) [e.g. Paganoni et al. 2019; Velayatham et al. 2019].

The North Carnarvon Basin records a complex and protracted history of magmatic activity during the Late Jurassic-to-Early Cretaceous (Figure 1B). A large magmatic body, thought to be mafic-to-ultramafic in composition and characterised by high seismic velocities, was emplaced in the lower crust during the Middle Jurassic [e.g. Frey et al. 1998; Rey et al. 2008; Rohrman 2013; Rohrman 2015]. Emplacement of this magmatic 


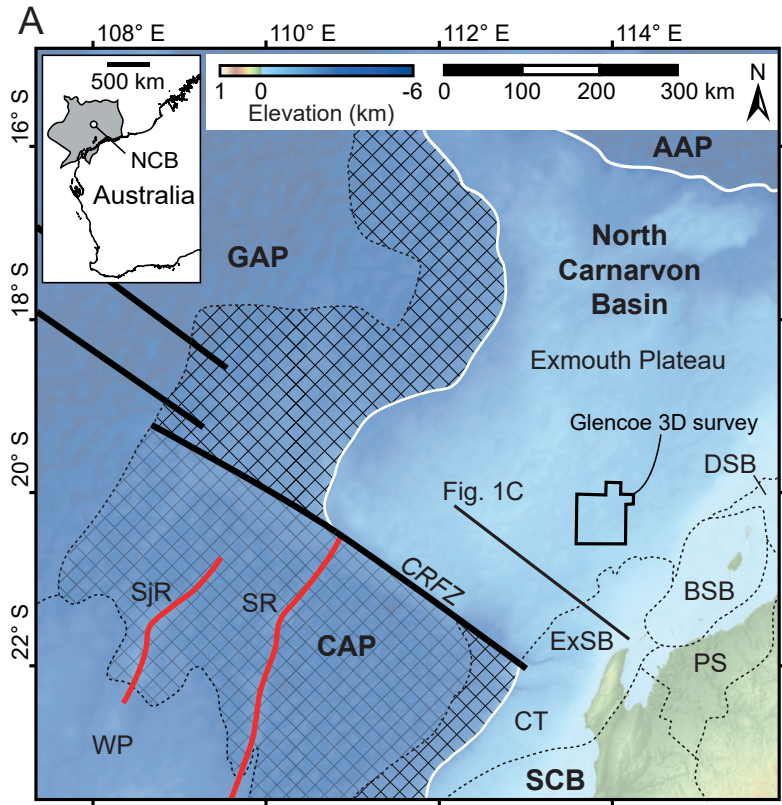

Key to $[A]$ .. Tectonic element boundary Seaward limit of unambiguous continental crust Continent-ocean transition zone XX (Symonds et al., 1998) Continent-ocean transition zone (Reeve, 2017) Extinct spreading centre - (Robb et al., 2005) - Fracture zones

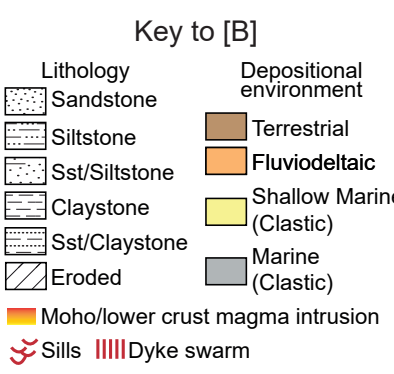

Key to [C]

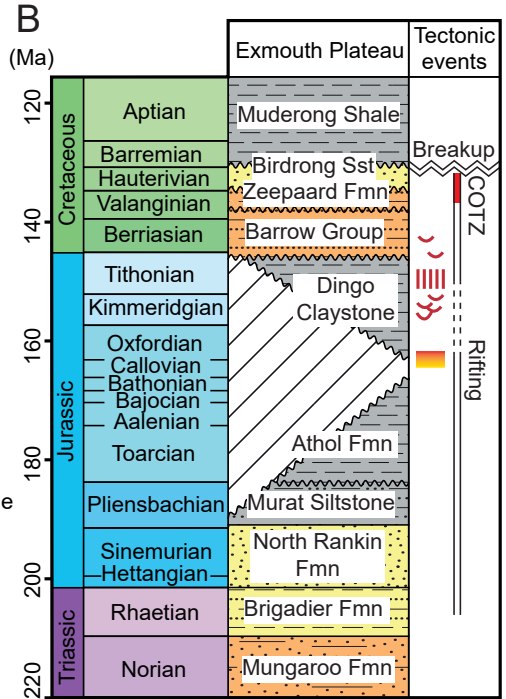

Triassic $\square$ Jurassic $\square$ Early Cretaceous (Barrow Group) $\quad \square$ Post-breakup Early Cretaceous (Zeepaard Formation (Fmn), Birdrong Sandstone (Sst))
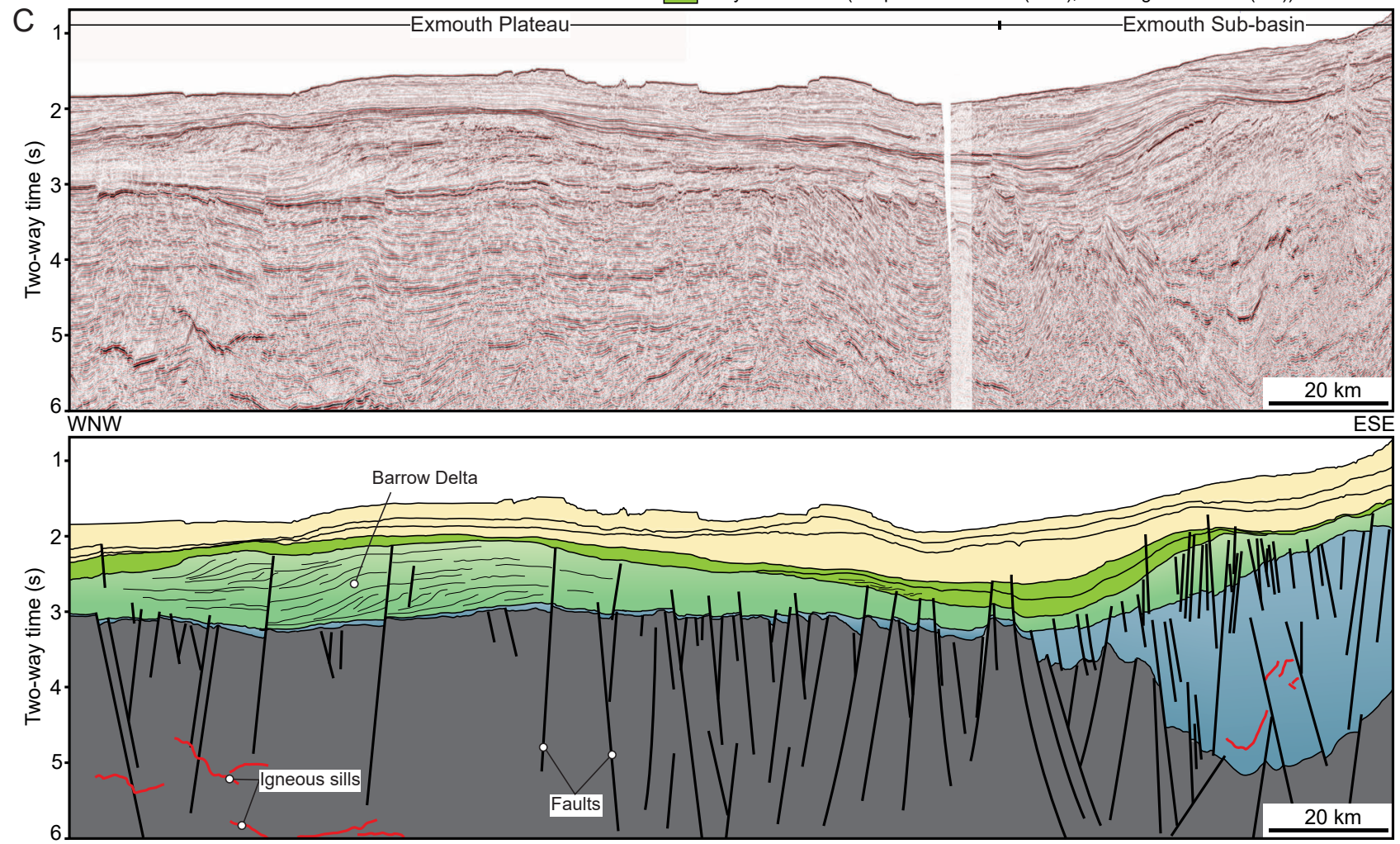

Figure 1: [A] Map of offshore NW Australia highlighting principal tectonic elements, including: $N C B=$ North Carnarvon Basin, $\mathrm{SCB}=$ South Carnarvon Basin, ExSB = Exmouth Sub-basin, BSB = Barrow Sub-basin, DSB = Dampier Subbasin, $\mathrm{PS}=$ Peedamullah Shelf, WP = Wallaby Plateau, $\mathrm{CAP}=$ Cuvier Abyssal Plain, GAP = Gascoyne Abyssal Plain, $\mathrm{AAP}=$ Argo Abyssal Plain, $\mathrm{SR}=$ Sonne Ridge, $\mathrm{SjR}=$ Sonja Ridge, $\mathrm{CRFZ}=$ Cape Range Fracture Zone. Elevation data are based on the 2009 Australian Bathymetry and Topography grid (Geoscience Australia). [B] Stratigraphic column for the Exmouth Plateau summarising the age, dominant lithology, and generalised depositional environment for key units. Important tectonic and magmatic events, including the evolution from continental rifting through to continent-ocean transition zone (COTZ) development and continental breakup are also shown [based on Hocking et al. 1987; Longley et al. 2002; Magee and Jackson 2020; Tindale et al. 1998]. [C] Uninterpreted and interpreted 2D seismic line across the Exmouth Plateau and Exmouth Sub-basin. See [A] for location. 
A

A - Normal faults
Sill
$\ldots \ldots . .$. Underlying dyke trace
$\bigcirc \quad$ Borehole

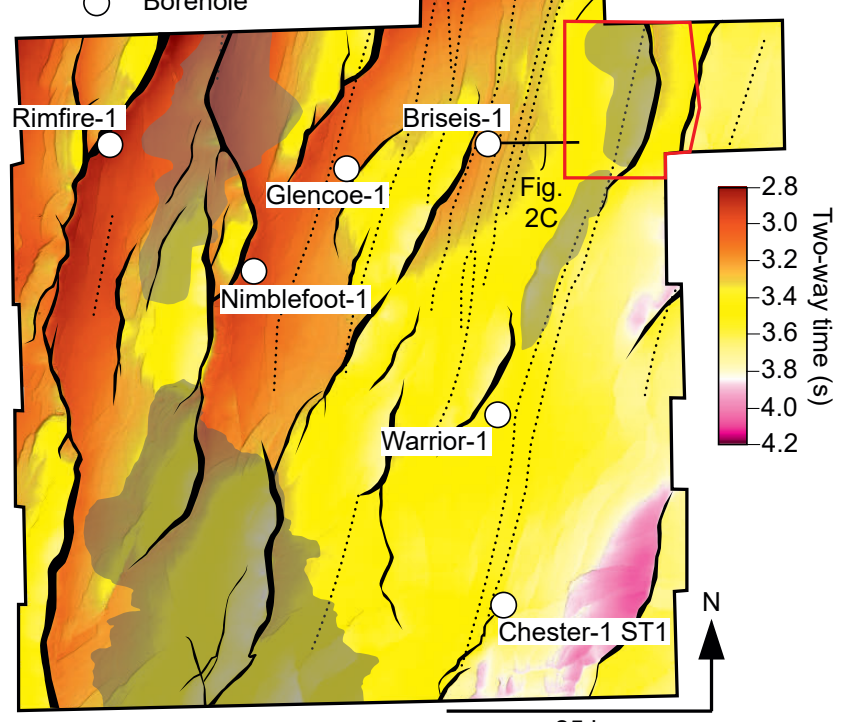

B

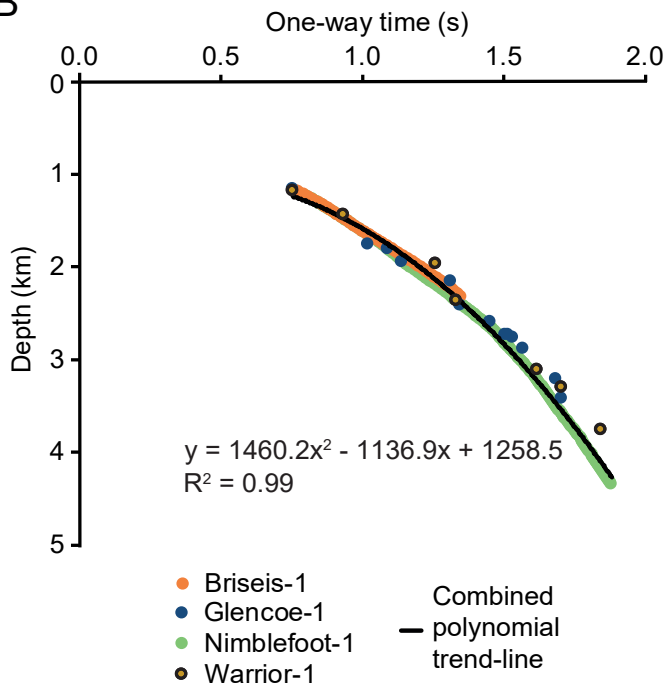

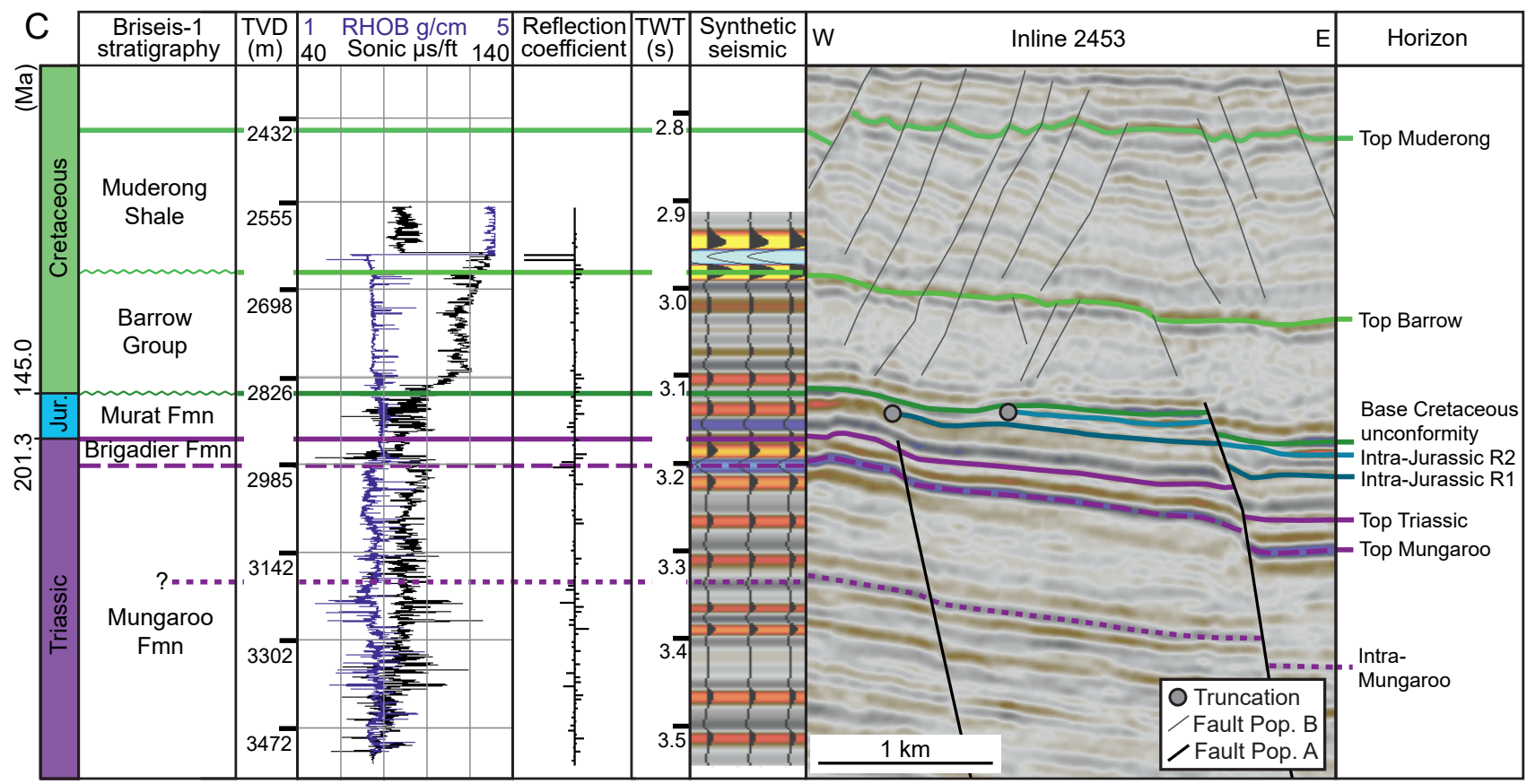

Figure 2: $[\mathrm{A}]$ Time-structure map of the Top Mungaroo horizon showing borehole locations and major tectonic normal faults. Dyke traces from Magee and Jackson [2020]. See Figure 1A for location. [B] Time-depth plot for borehole data from Briseis-1, Glencoe-1, Nimblefoot-1, and Warrior-1. A second-order polynomial trend-line is plotted through all data to define the time-depth relationship. [C] Borehole data from Briseis-1 and associated synthetic seismic trace compared to the actual seismic data (see $[A]$ for line location). $R H O B=$ density log, sonic $=a$ measure of how slow acoustic waves travel through a formation, reflection coefficient $=$ proportion of a reflected waves amplitude relative to its incident wave, TWT = two-way travel-time. Mapped horizons and fault populations (pop.) highlighted. 
body may have promoted regional uplift and formation of the Callovian unconformity [e.g. Rohrman 2015]. Extensive sill-complexes across the North Carnarvon Basin (e.g. Figure 2A), which dating of intrusioninduced forced folds and vent complexes indicate were emplaced at least during the Kimmeridgian, may have been fed by this mafic-to-ultramafic magmatic body [e.g. Frey et al. 1998; Magee et al. 2013b; Magee et al. 2017; Rey et al. 2008; Rohrman 2013]. A transition from sill-complex emplacement to intrusion of an extensive dyke swarm occurred at $\sim 148 \mathrm{Ma}$, coincident with the formation of the Base Cretaceous unconformity [Magee and Jackson 2020]. Magee and Jackson [2020] interpret that one of the NNE-trending dykes within the Exmouth Dyke Swarm underlies the sill studied here (Figure 2A). The last and main phase of magmatism across the North Carnarvon Basin resulted in development of the continent-ocean transition zones and associated volcanics during break-up (e.g. seaward-dipping reflectors), as well as sporadic sill intrusions within the basin interior [e.g. Hopper et al. 1992; Magee et al. 2013a; Mark et al. 2019; Rey et al. 2008; Symonds et al. 1998].

\section{DAta AND METhods}

\subsection{Data}

Here we use the publicly available, high-quality, timemigrated Glencoe 3D seismic reflection survey that was acquired by CGGVeritas in 2007-2008 (Figure 1A and 2A). Data were recorded with a line spacing of $25 \mathrm{~m}$ using ten $6-\mathrm{km}$ long streamers, with 480 channels recording to $\sim 8 \mathrm{~s}$ two-way time (TWT) at a sample interval of $2 \mathrm{~ms}$. The seismic source had a volume of $3460 \mathrm{in}^{3}$ and was fired at shot point intervals of $12.5 \mathrm{~m}$ at a tow depth of $7 \mathrm{~m}$. Full-fold, the dataset covers an area of approximately $4042 \mathrm{~km}^{2}$ (Figure 2A). Seismic data were processed to zero-phase and are here displayed with SEG standard polarity, whereby a downward increase in acoustic impedance corresponds to a peak (red-toyellow on seismic sections) and a downward decrease in acoustic impedance as a trough (blue or black on seismic sections).

We use data from the Briseis-1, Nimblefoot-1, Warrior-1, and Glencoe-1 boreholes to determine (Figure 2): (i) the age of the mapped horizons and the lithology (and age) of the stratigraphic units they bound; and (ii) a time-depth relationship, constrained by checkshot data, which allows us to depth-convert measurements within the sedimentary sequence from seconds twoway time to metres (Figure 2B; Supplementary Table 1). By measuring the dominant wavelength $(\lambda=26.3 \mathrm{~m})$ of stratal seismic reflections in the interval of interest, we estimate that the limit of separability $(\lambda / 4$; where $\lambda$ is the seismic wavelength) and visibility $(\lambda / 30)$ for the sedimentary succession are $\sim 6.6$ and $\sim 0.9 \mathrm{~m}$, respec- tively.

No boreholes intersect the igneous intrusion within our study area, but data from the nearby Rimfire-1 and Chester-1 ST1 wells (Figure 2A), which intersect a $\sim 10 \mathrm{~m}$ thick intrusion and an $\sim 18 \mathrm{~m}$ wide dyke respectively, suggests intrusions in the region are likely mafic [Childs et al. 2013; Magee and Jackson 2020; Moig and Massie 2010]. Although there is no velocity information available for the thin intrusions intersected by Rimfire-1 and Chester-1 ST1, we consider the sill we study has a seismic velocity of $\sim 5.550 \pm 0.555 \mathrm{~km} \mathrm{~s}^{-1}$; this range is based on velocity data acquired from mafic intrusions in other sedimentary basins [e.g. Magee et al. 2019a; Skogly 1998; Smallwood and Maresh 2002]. At the level of the intrusion in our study area, the dominant frequency of the data is $\sim 25 \mathrm{~Hz}$, which coupled with a seismic velocity of $\sim 5.550 \pm 0.555 \mathrm{~km} \mathrm{~s}^{-1}$ suggests the limits of separability and visibility for the sill are $\sim 56.0 \pm 5.6 \mathrm{~m}$ and $\sim 7.0 \pm 0.7 \mathrm{~m}$, respectively. Where the sill has a thickness between these limits of separability and visibility, it is expressed in the data as a tuned reflection package; i.e. seismic energy reflected from the top and base intrusive contacts combines on its return to the surface and cannot be deconvolved [e.g. Eide et al. 2017; Smallwood and Maresh 2002]. Where the sill is thicker than the limit of separability, its top and base reflections can be distinguished, allowing us to use our inferred velocity range to depth-convert the intrusions measured thickness from seconds TWT to metres.

\subsection{Methods}

\subsubsection{Seismic interpretation}

To define the geometry of the studied sill, which around its outer edges typically appears as a tuned reflection package, we mapped two seismic horizons (Top and Base Sill). We also mapped eight seismic horizons within the host sedimentary sequence to provide a seismic-stratigraphic framework for our analyses. Biostratigraphic data from the Briseis-1 borehole, which is closest to the study area, provides direct age constraints on five mapped horizons (Figure 2C): Top Muderong ( 113 Ma), Top Barrow Group ( 138 Ma), Base Cretaceous unconformity ( $148 \mathrm{Ma})$, Top Triassic ( 201 Ma), and Top Mungaroo (near Norian-Rhaetian boundary; $208 \mathrm{Ma}$ ). Four of these biostratigraphically dated horizons were tied to the seismic reflection data by creation of a synthetic seismogram for the Briseis-1 well-log data; well-logs only extend between depths of 2563-3548 m TVD (total vertical depth beneath the drill floor) and thus do not intersect the Top Muderong horizon (Figure 2C). The location of the Top Muderong was instead constrained by using checkshot data from Briseis- 1 to convert the measured depth of the horizon in metres to TWT (Figure 2B). In addition to the five dated horizons we mapped an intra-Mungaroo Formation horizon encountered in Briseis-1, but for which the 
A Syn-intrusion
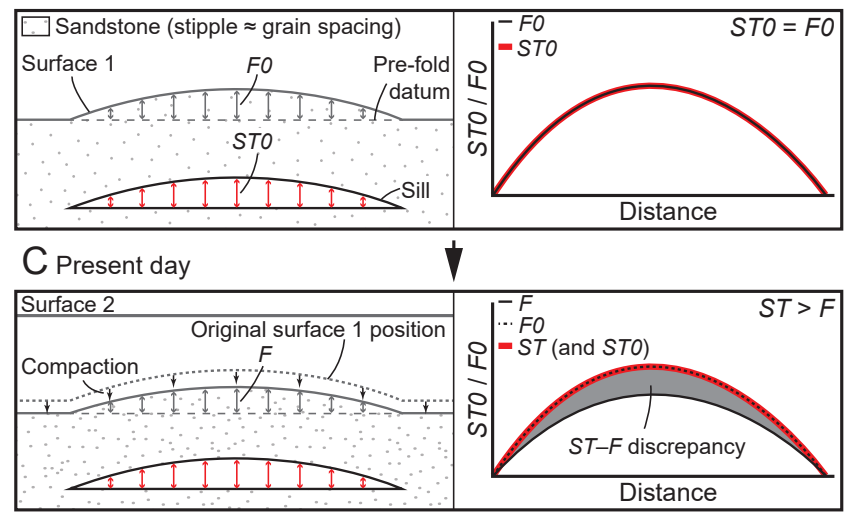

B Syn-intrusion
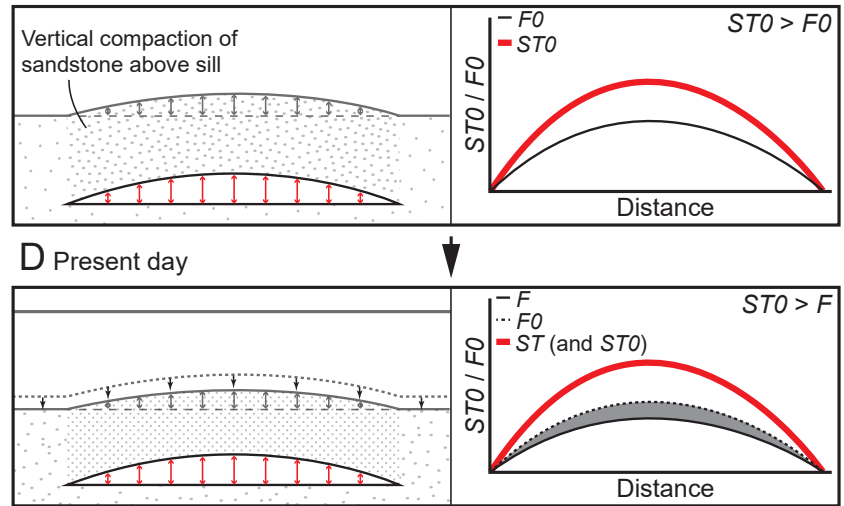

Figure 3: [A] Schematic showing uplift above a sill if accommodated purely by elastic bending of a sandstone overburden. A plot of showing how original sill thickness (ST0) and fold amplitude (F0), based on defining a pre-fold datum, change with distance from left to right is included; note $S T 0$ and $F 0$ are equal. [B] Schematic showing uplift above a sill if vertical compaction of the overburden accompanies elastic bending; $F 0$ is less than $S T 0$ across the profile. [C] and [D] Schematics of $[A]$ and $[B]$ following burial-related compaction, respectively. In both cases, the present-day fold amplitude $(F)$ is less than $S T 0$.

exact age remains unconstrained (i.e. Intra-Mungaroo; Figure $2 \mathrm{C}$ ). We also mapped two horizons above the Top Triassic, but these could not be dated as they were eroded by the Base Cretaceous unconformity and do not extend to the location of Briseis-1; we term the stratigrapically oldest of these horizons Intra-Jurassic R1, and the other Intra-Jurassic R2 (Figure 2C). All horizons were mapped across the study area, except for the Intra-Mungaroo horizon, which was only identified locally as sub-sill imaging often hindered its recognition. Thickness maps (isochores) between various combinations of the mapped horizons were used to assess deformation of the sedimentary sequence through time.

\subsubsection{Forced fold analysis}

If the space for emplacement of a sub-horizontal, tabular magma body (e.g. a sill) is fully generated by elastic bending, we may expect the original intrusion thickness $(S T 0)$ to equal the syn-intrusion amplitude $(F 0)$ of the resultant fold (Figure 3A) [e.g. Bunger and Cruden 2011; Galland and Scheibert 2013; Goulty and Schofield 2008; Hansen and Cartwright 2006; Pollard and Johnson 1973]. However, if viscoelastic and/or plastic processes (e.g. compaction) also contribute to generating space for intruding magma, and thus reduce uplift, we may expect $S T 0>F 0$ (Figure 3B) [e.g. Jackson et al. 2013; Magee et al. 2013b; Magee et al. 2019b; Schmiedel et al. 2017]. We calculate the presentday, vertical fold amplitude $(F)$ every $10 \mathrm{~m}$ along a representative seismic line by measuring and depthconverting the distance between the top fold horizon and a projected pre-fold datum (Figure 3) [e.g. Hansen and Cartwright 2006]. We also calculate the presentday, vertical sill thickness (ST) every $10 \mathrm{~m}$ along the same profile and compare this to $F$ (Figure 3). Because burial-related compaction likely reduces fold amplitude through time (i.e. F0 > F; Figure 3C, D), without affecting the thickness of typically incompressible intrusions (i.e. we assume $S T=S T 0$ ), we backstrip and decompact $F$ to estimate $F 0$ (Figure 3C, D) [e.g. Magee et al. 2019a].

Airy backstripping of strata involves restoration of its initial porosity $\left(\phi_{0}\right)$ by removing the effects of overburden loading [e.g. Sclater and Christie 1980], and thus requires knowledge of: (i) the current porosity $(\phi)$ of a given sedimentary sequence; and (ii) the compaction length scale $(l)$, which is the inverse of the compaction coefficient and estimates the rate of compaction with increasing burial depth. Given that no boreholes penetrate the entire folded sequence, either at the actual fold or elsewhere in the 3D survey, we could not estimate $\phi$ and $l$ from our data. Instead, following the method outlined by Magee et al. [2019a], we computed an envelope of potential backstripped $F 0$ using a range of realistic $\phi_{0}(0.7-0.25)$ and $l(3.7-1.4)$ values for claystones and sandstones as these rock types dominate the folded siliciclastic sequence studied (e.g. Figure 1B).

There are several limitations to our method for comparing $S T 0$ and F0. First, we assume that the measured sill thickness $(S T)$ is equal to $S T 0$ (Figure 3), but acknowledge that post-emplacement magma expulsion and/or contraction during crystallisation could mean ST < STO [e.g. Caricchi et al. 2014; Chaussard 2016; Magee et al. 2019a]. The use of incorrect seismic velocities may also introduce imprecision into our depth-conversion of $S T$ and $F$, although we consider that the range of velocities used for the sill and those for the borehole-constrained folded stratigraphy minimises this error; however, our method does not ac- 
count for potential lateral variations in seismic velocity across the sill or forced fold, which could reflect changes in lithology. Finally, we note that the Airy backstripping method applied assumes the folded layers had no flexural strength (i.e. elastic thickness) [Magee et al. 2019a]. Yet if the folded rock layer had an elastic thickness, its fold amplitude would have been suppressed [e.g. Hardy and Finch 2006; Oehlers et al. 1994]. We note that folding of a layer with a flexural strength would promote lengthening of the fold beyond the limits of the underlying forcing mechanism (i.e. the sill); our assumption that the folded sequence has no flexural strength may thus be partially validated by an observed coincidence between the fold outline (i.e. where fold amplitude is zero) and the sill edge [Hansen and Cartwright 2006; Magee et al. 2019a]. Overall, whilst these limitations may cause $F 0$ to deviate from $S T 0$, we consider their effects are likely negligible and suggest that a difference between $S T 0$ and $F 0$ of $>5 \%$ can probably be related to syn-emplacement processes, as opposed to post-emplacement modification of $S T 0$ or simply reflecting measurement errors [Magee et al. 2019a].

\subsubsection{Fault kinematics}

To establish the geometrical and kinematic relationships between the sill, its overlying forced fold, and faulting, we conducted throw analysis of the major, N$\mathrm{S}$ striking, W-dipping fault (Fault 1) that borders the eastern edge of the sill. Throw-depth $(T-z)$ and throwdistance $(T-x)$ profiles are commonly used to assess the geometry and infer the kinematics of normal faults [e.g. Baudon and Cartwright 2008; Hongxing and Anderson 2007; Jackson et al. 2017; Rotevatn et al. 2019]. For example, local throw minima expressed in $T-x$ profiles may represent breached relays formed during fault segment linkage [e.g. Cartwright et al. 1996; Mansfield and Cartwright 1996; Peacock and Sanderson 1991]. Furthermore, changes in throw gradient (in $T-z$ or $T-x$ profiles) can help identify intervals containing syntectonic growth strata, which thus constrain periods of active faulting [e.g. Ferrill and Morris 2001; Walsh and Watterson 1989]. Although we were not able to identify piercing points (e.g. channels) either side of Fault 1 to establish whether there was any along-strike offset of strata, we assume faulting was dip-slip and that measured throw patterns reflect displacement distribution.

We compiled a throw-depth plot for a representative seismic line crossing Fault 1, near its centre, by measuring the vertical offset of each mapped horizon. Where horizons adjacent to Fault 1 appear deflected, we projected their regional trend to define the fault cut-off and thereby account for both brittle and ductile strains [e.g. Mansfield and Cartwright 1996]. We extracted expansion indices (EI) from the same line; EI reflect the difference between the hanging wall and footwall thickness of a given stratal package [e.g. Cartwright et al.
1998; Jackson et al. 2017; Thorsen 1963]. These quantitative fault measurements allow us to constrain the main periods of fault activity, as well as temporal variations in the relative rates of sediment accumulation and fault throw, at least in two dimensions [e.g. Jackson et al. 2017]. We analysed along-strike variations in fault throw $(T-x)$ by measuring Top Mungaroo hanging wall and footwall cut-offs every $127 \mathrm{~m}$ along Fault 1 on sections oriented normal to the fault; we selected this horizon for $T-x$ analysis because it is well-imaged and occurs at a similar stratigraphic level to the sill. To assess the relationship between sill thickness and fault throw, we also measured sill thickness in the hanging wall of the fault, on the same profiles, every $100 \mathrm{~m}$ along strike.

\section{Sill-FAULT-FOLd GEOMETRY AND SPATIAL RELATIONSHIPS}

\subsection{Sill characterisation}

The studied sill comprises a $>13.4 \mathrm{~km}$ long, $\mathrm{N}$-trending, strata-concordant inner sill, bound on its eastern and most of its western flanks by inwardly inclined sheets, and located within the Mungaroo Formation (Figure 4). The Top Sill contact corresponds to a high-amplitude, positive reflection, marking a downward increase in acoustic impedance across the sedimentary strata-sill interface, and currently occurs at a maximum depth of $\sim 3.81 \mathrm{~s}$ TWT (Figure 4A, D-F). Across much of this inner sill, we identify and map a discrete Base Sill reflection, which has a high amplitude and negative polarity (i.e. it marks the downward decrease in acoustic impedance; Figure 4B, D-F). Within the southern and northwestern sector of the inner sill, we observe no discrete Base Sill contact and the sill is instead expressed as a tuned reflection package; in these areas we map the Base Sill as the lowermost reflection in the tuned package but note this may not correlate to the true base sill contact (Figure 4B, D-F). Along its eastern margin and the southern $\sim 7.2 \mathrm{~km}$ of its western edge, the sill transitions into transgressive, inward-dipping inclined sheets, which also correspond to tuned reflection packages (Figure 4). Each inclined sheet extends up into the overlying Jurassic succession, but appear to terminate below Intra-Jurassic R1 horizon (e.g. Figure 4B). The eastern inclined sheet coincides with a major, N-Sstriking, W-dipping, tectonic fault (Fault 1; Figure 4). Where both eastern and western inclined sheets are developed, the entire sill is relatively narrow (up to $4.8 \mathrm{~km}$ wide) and the inner sill is $\$ 3.2 \mathrm{~km}$ wide (Figure 4). North of this zone, where there is no western inclined limb, the sill abruptly widens (up to $6.4 \mathrm{~km}$ wide) and has a convex-outwards, lobate western termination (Figure $4 \mathrm{~A}-\mathrm{C}, \mathrm{F}$ ).

Distinguishing discrete Top Sill and Base Sill reflections across much of the inner sill allows us to assess vertical sill thickness in metres (Figure 4C; e.g. Supplementary Table 2). We show the inner sill is locally 

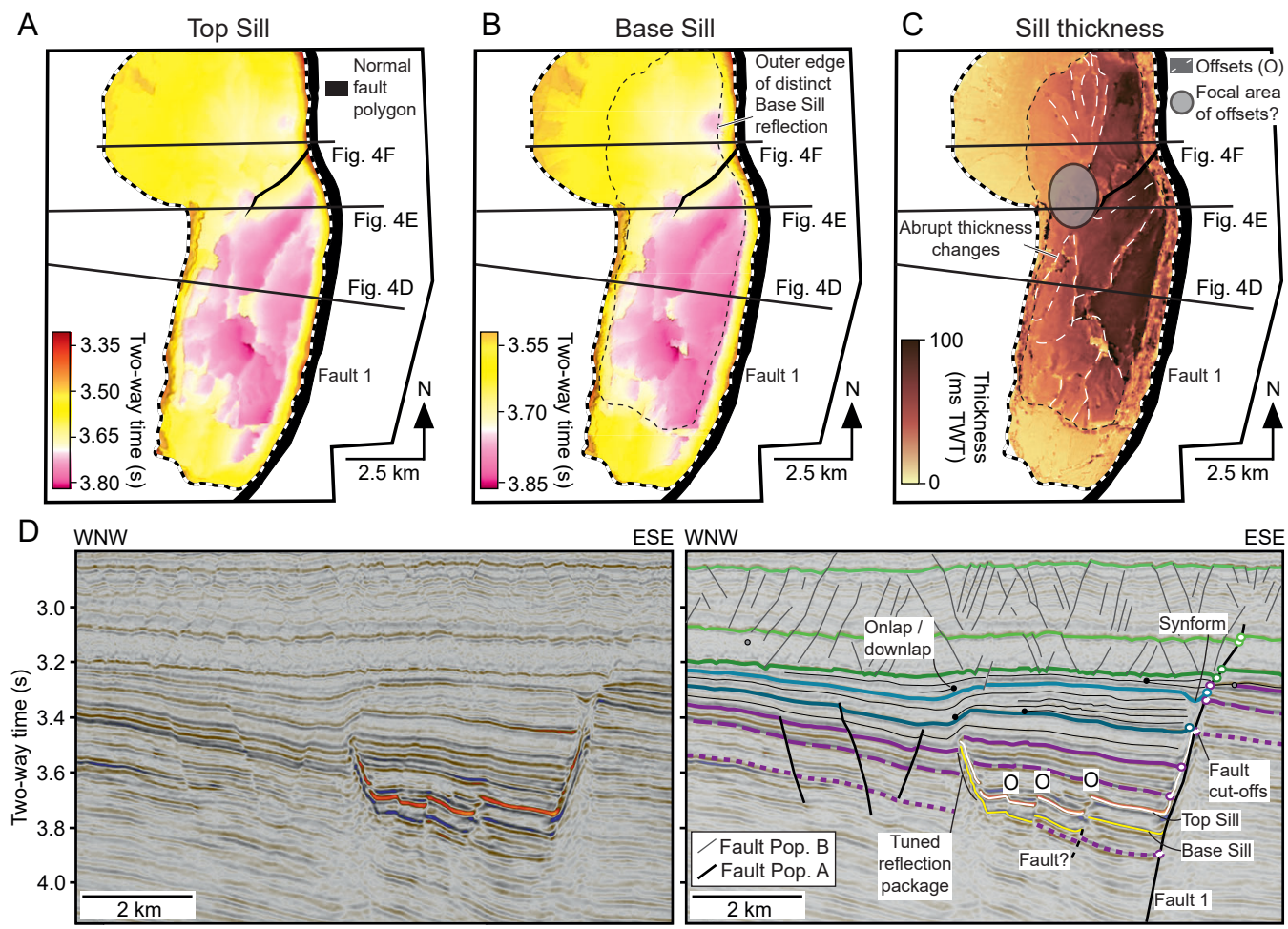

ESE WNW

ESE
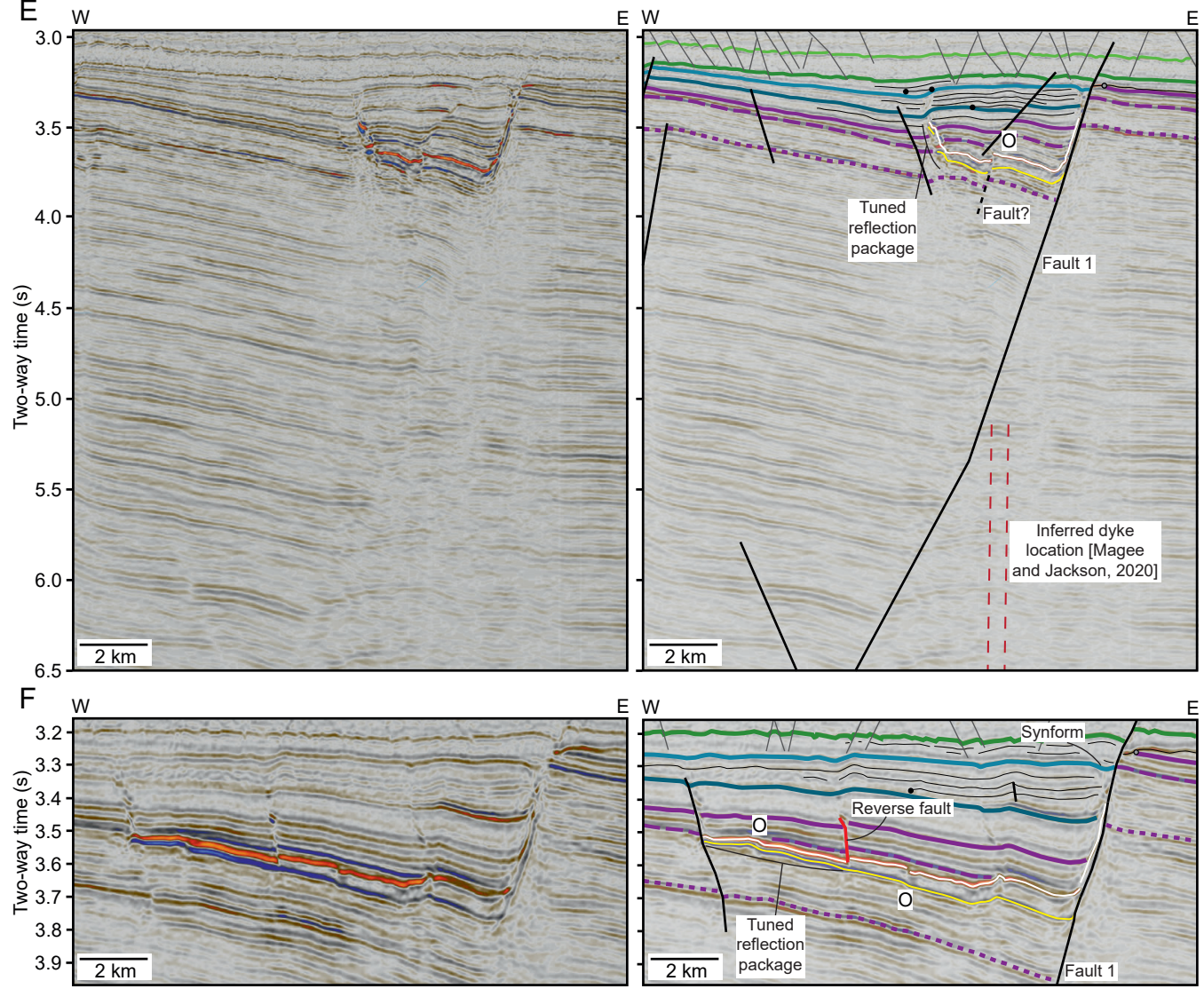

Figure 4: $[A-C]$ Maps showing the time-structure of $[A]$ the Top and $[B]$ Base sill horizons, as well as $[C]$ the vertical thickness difference (in time) between them. The Base Sill horizon was only mapped where it could be distinguished as a distinct reflection. [D-F] Uninterpreted and interpreted seismic sections detailing the sill geometry, including the location of vertical offsets $(0)$ in sill reflections, and associated host rock structure. See Figure $4 \mathrm{~A}-\mathrm{C}$ for line locations and Figure $2 \mathrm{C}$ for horizon key. 
up to $\sim 98 \mathrm{~ms}$ TWT $(\sim 272 \pm 27 \mathrm{~m})$ thick (Figure $4 \mathrm{C})$. In the eastern half of the intrusion where the inner sill is bound by Fault 1, its thickness varies between $\sim 60$ $90 \mathrm{~ms}$ TWT $(\sim 166 \pm 17 \mathrm{~m}$ to $249 \pm 25 \mathrm{~m})$, broadly decreasing westwards to $40-60 \mathrm{~ms}$ TWT $(\sim 111 \pm 11 \mathrm{~m}$ to $166 \pm 17 \mathrm{~m}$ ) (Figure 4C). The inclined sheets, as well as the southern inner sill tip and its arcuate westwards termination, are expressed as tuned reflection packages, such that their thickness can only be defined as being between the limits of separability $(56.0 \pm 5.6 \mathrm{~m})$ and visibility $(\sim 7.0 \pm 0.7 \mathrm{~m})$ for the data (e.g. Figure $4 \mathrm{D}-\mathrm{F})$. Across the inner sill we recognise discrete and abrupt changes in thickness where (Figure 4C): (i) the Top Sill and Base Sill reflections become tuned, and (ii) vertical offsets in the Top Sill and Base Sill reflections occur, which appear linear in plan-view and are radially disposed around a focal area (see also Figure 4D-F). Stratigraphic reflections immediately above and below these vertical offsets are typically continuous and rarely appear displaced (Figure 4D-F).

\subsection{Stratigraphic framework and forced fold charac- terisation}

The Top Mungaroo horizon dips eastwards towards Fault 1 (Figure 4D-F, 5A). Local, abrupt changes in Top Mungaroo depth are observed across the study area where the horizon (Figure 5A): (i) is offset by up to $\sim 0.5 \mathrm{~s}$ TWT across minor, $\sim \mathrm{NE}-\mathrm{SW}$-striking normal faults (Fault Population A), and (ii) overlies or is crosscut by the western edge of the sill. Although the underlying Intra-Mungaroo horizon cannot be mapped fully across the study area, where identified, it broadly parallels the Top Mungaroo horizon (e.g. Figure 4DF). In most places the Intra-Mungaroo horizon is located $>0.75 \mathrm{~s}$ TWT beneath the Top Mungaroo horizon, except where it extends beneath the sill and the Top Mungaroo is locally uplifted (e.g. Figure 4D-F). Within the Triassic strata, a subtle vertical zone of disruption, which extends downwards from Fault 1 at $\sim 5 \mathrm{~s}$ TWT, is present beneath the sill (Figure 4E); this vertical zone of disruption has previously been interpreted as the seismic expression a dyke [Magee and Jackson 2020].

Intra-Jurassic R2 is only observed in the hanging wall of Fault 1, where it is locally offset by faults within Fault Population A (Figure 5B). Uplift of supra-sill horizons, relative to their projected regional trends, is clearly demonstrated by Intra-Jurassic R2 where the margins of a dome-shaped fold directly overlie the western and eastern lateral tips of the sill (Figure 4D-F and 5B). The western margin of the dome-shaped fold is a $\mathrm{W}$ verging monocline, which includes folded strata between the Top Triassic and Intra-Jurassic R2, whereas its eastern margin has a subtle synformal geometry immediately adjacent to Fault 1 that is only expressed between Intra-Jurassic R1 and R2; below Intra-Jurassic $\mathrm{R} 1$ there is no apparent folding of horizons adjacent to Fault 1 (Figure 4D-F and 5C). Above the deepest part of the Top Sill horizon (i.e. $~ 3.81 \mathrm{~s}$ TWT), the Intra-Jurassic R2 horizon is currently located at $\sim 3.25 \mathrm{~s}$ TWT. Although relatively flat-topped, superimposed onto the dome-shaped fold at the Intra-Jurassic R2 level are three broad areas of elevated relief (up to $\sim 3.26 \mathrm{~s}$ TWT), separated by subtle lows ( $3.30 \mathrm{~s}$ TWT; Figure $5 \mathrm{~B})$. Within the northern-most region of elevated relief is a thin narrow $(<100 \mathrm{~m}$ wide), arcuate depression that extends for $\sim 3 \mathrm{~km}$ along strike and coincides with an apparent reverse fault (Figure $4 \mathrm{~F}$ and $5 \mathrm{C}$ ). $\mathrm{Nu}$ merous sub-circular and elliptical, $\lesssim 1 \mathrm{~km}$ wide, $\lesssim 0.2 \mathrm{~s}$ TWT deep depressions are observed within the domeshaped fold towards its western margin along IntraJurassic R2 (Figure 5B, C). Between the Top Mungaroo and Intra-Jurassic R2 horizons, there is a general thickening of strata towards Fault 1 (Figure 5C); this thickening in part relates to the presence of stratigraphic reflections extending westwards from Fault 1 that onlap onto Intra-Jurassic R1 (e.g. Figure 4C). There is no apparent change in this regional thickening trend of the Top Mungaroo-to-Intra-Jurassic R2 strata above the western edge of the sill (Figure 5C). Where depressions are observed at Intra-Jurassic R2 and/or the Top Mungaroo, the intervening strata is locally thinner than adjacent areas (Figure 5C). In cross-section, these depressions appear to be filled by overlying reflections and are underlain by sub-vertical pipes that extend down to the sill (e.g. Figure 5D).

The clear dome-shaped fold observed at IntraJurassic R2 and its internal variations in elevation are subtly expressed across the Base Cretaceous unconformity (Figure 5E). Compared to deeper stratigraphic horizons, offset (up to $\sim 0.1 \mathrm{~s}$ TWT) of the Base Cretaceous unconformity across Fault 1 is reduced and very minor changes in depth define a polygonal pattern (Figure 5E). Strata between Intra-Jurassic R2 and the Base Cretaceous unconformity display complex thickness variations (Figure 5F): (i) there is a broad thickening towards Fault 1, interrupted by the dome-shaped fold across which strata is relatively thin $(\sim 0.04-0.09 \mathrm{~s}$ TWT), (ii) a zone of thickening parallel to Fault 1 above the eastern sill tip, and overlying the synform developed along Intra-Jurassic R2, and (iii) localised zones of thickening, overlying the sub-circular depressions on Intra-Jurassic R2. The thinning of strata bound by the Intra-Jurassic R2 and Base Cretaceous unconformity horizons across the dome-shaped fold is facilitated by the onlap of reflections onto the fold limbs (e.g. Figure $4 \mathrm{D}, \mathrm{E})$.

\subsubsection{Comparison between sill thickness and fold am- plitude}

We compare the present-day vertical sill thickness (ST), which we consider equal to $S T 0$, and fold amplitude $(F)$ at Intra-Jurassic R2 along a selected seismic section (i.e. Figure $4 \mathrm{~B}$ ) where the sill is $\sim 4.5 \mathrm{~km}$ wide (Figure 6; Supplementary Tables 2 and 3). We show 
A

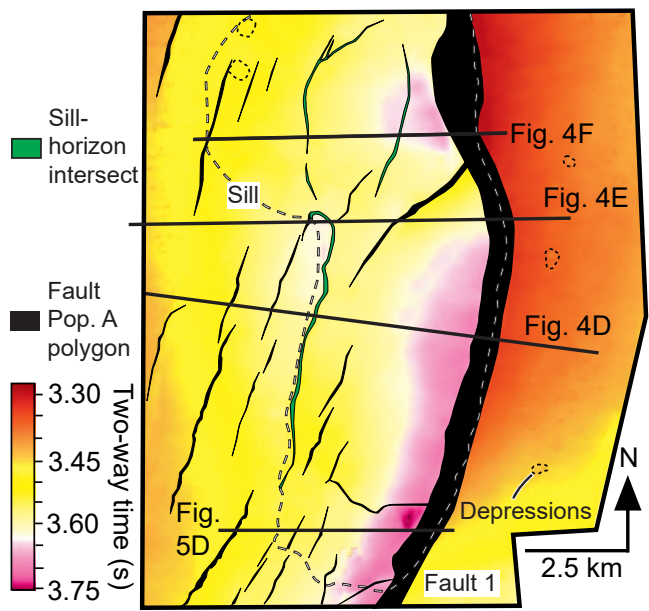

C Top Mungaroo - Intra-Jurassic R2 thickness

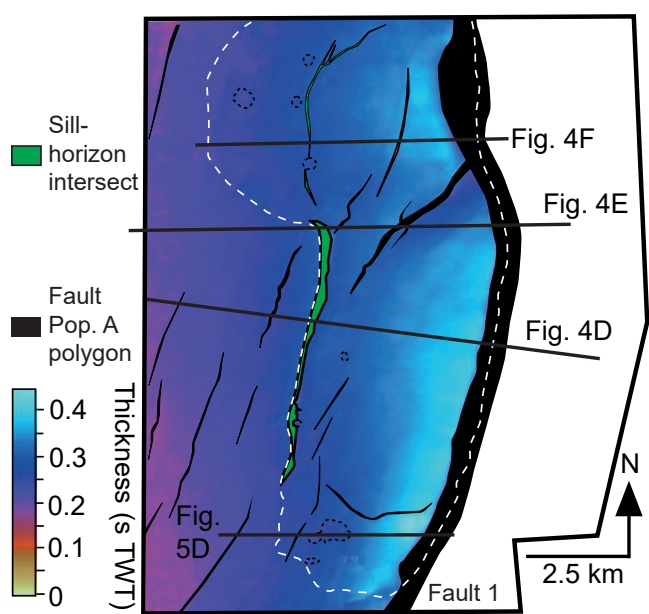

E

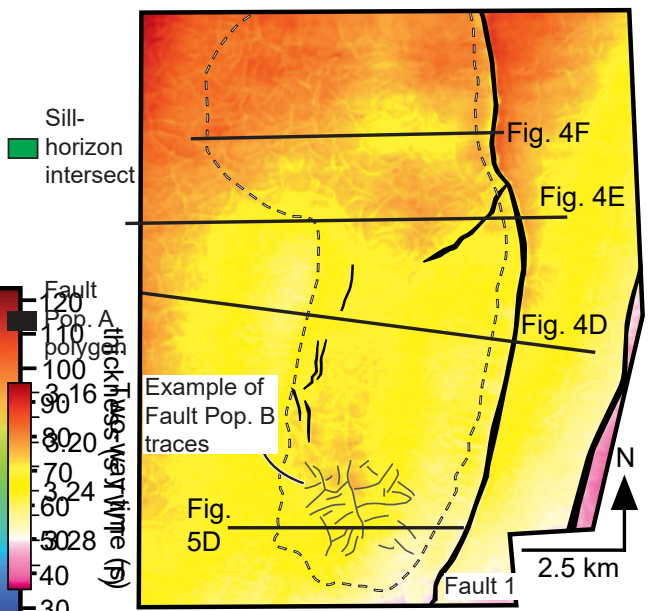

B
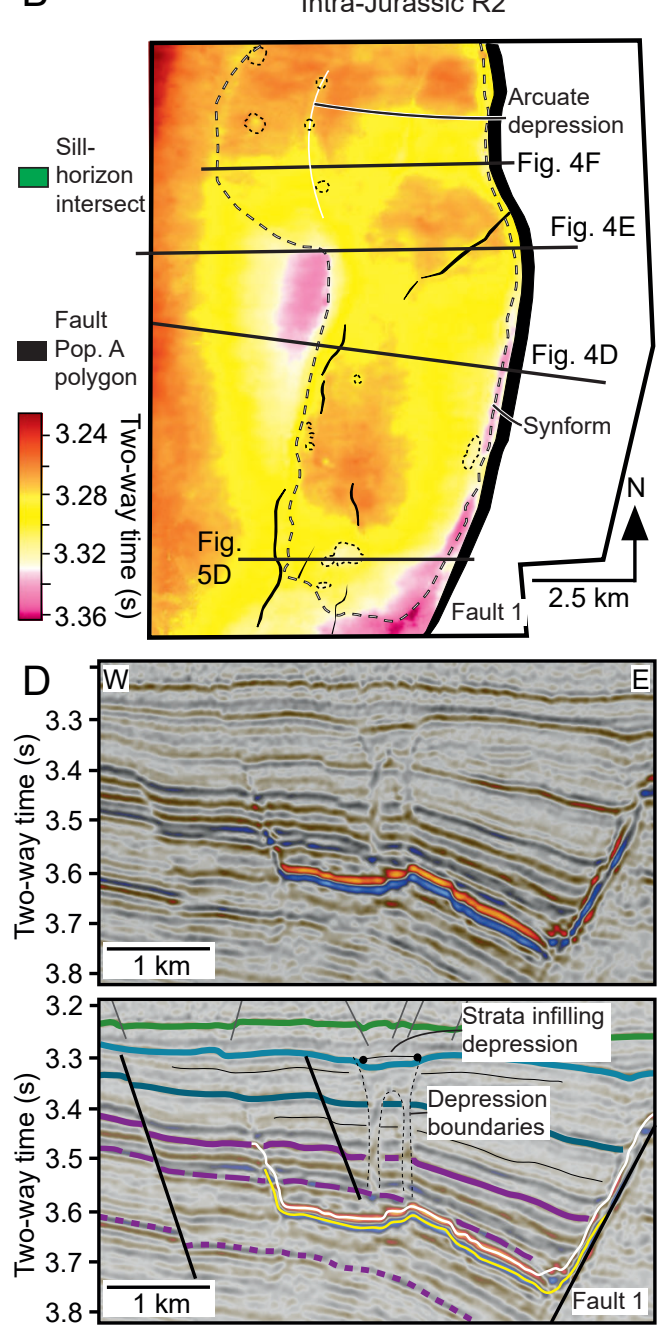

$\mathrm{F}$

Intra-Jurassic R2 - Base Cretaceous Unconformity thickness

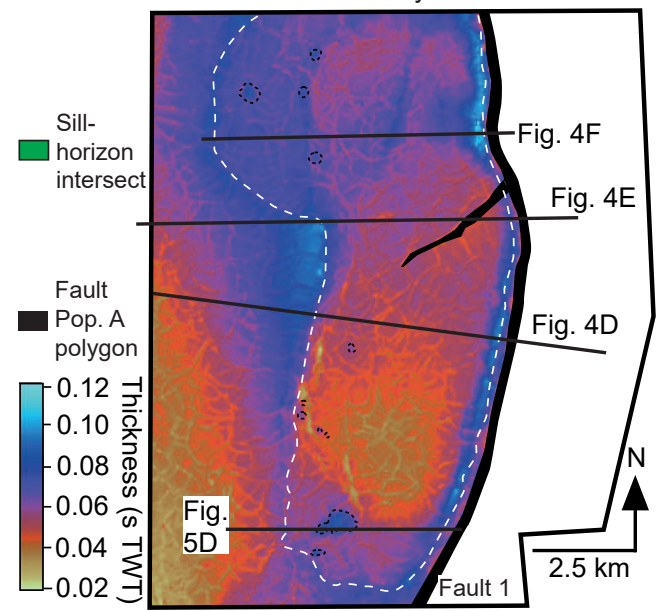

Figure 5: [A] Time-structure map of the Top Mungaroo horizon showing Fault Population (Pop.) A polygons and sill outline. See Figure 2A for location. [B] Time-structure map of the Intra-Jurassic R2 horizon. [C] Vertical thickness (in time) between the Top Mungaroo and Intra-Jurassic R2 horizons. [D] Uninterpreted and interpreted seismic section detailing the cross-section geometry of a depression observed along Intra-Jurassic R2. See Figure 5A-C, E, and $\mathrm{F}$ for line locations and Figure $2 \mathrm{C}$ for horizon key. [E] Time-structure map of the Base Cretaceous unconformity. Some Fault Population B traces interpreted; others omitted for clarity. [F] Vertical thickness (in time) between the Intra-Jurassic R2 and Base Cretaceous unconformity horizons. 
$S T$ ranges from $56.0 \pm 5.6 \mathrm{~m}$ at the edges of the inner sill to a maximum of $\sim 259 \pm 26 \mathrm{~m}$ (Figure 6; Supplementary Table 2); note we only measure $S T$ where the top and base sill contact reflections can be defined and thus do not take into account the tuned reflection packages defining the inclined sheets. The $S T$ profile can be sub-divided into four parts [i-iv] where $S T$ is relatively stable, separated by abrupt increases and decreases in $S T$ (Figure 6); $S T_{\text {mean }}$ of these parts decreases westwards from $\sim 204 \pm 20 \mathrm{~m}$ to $\sim 150 \pm 15 \mathrm{~m}$, respectively (Figure 6). The marked changes in $S T$ correspond to where steps occur within the sill reflection(s) (Figure $4 \mathrm{~B}, 6)$.

Along the selected seismic section, the fold is $\sim 4.8 \mathrm{~km}$ wide, extending slightly to the east and west of the underlying sill tips (Figure 4B and 6). The fold has a relatively flat top and is defined by a $\mathrm{W}$-verging monocline on its western limb (Figure $4 \mathrm{~B}$ and 6 ). On its eastern limb, the fold has a synformal geometry (Figure $4 \mathrm{~B}$ and 6); i.e. at the fault, the present-day fold amplitude $(F)$ is $\sim 75 \mathrm{~m}$ but above the eastern edge of the sill, which underlies the synform fold axis, $F$ is $\sim 47 \mathrm{~m}$ (Figure 6; Supplementary Table 2). Along the profile, the maximum measured $F$ of $\sim 116 \mathrm{~m}$ is $\sim 54 \pm 5 \%$ less than the maximum $S T$ (i.e. $259 \pm 26 \mathrm{~m}$ ) and the two areas are laterally offset by $\sim 0.59 \mathrm{~km}$ in $2 \mathrm{D}$ (Figure 6; Supplementary Tables 2 and 3). Overall, $S T>F$ by an average of $\sim 37 \pm 7 \%$, except where the inner sill transitions to the inclined sheets and across one of the sill steps (Figure 6). We observe no marked variations in $F$ where the sill appears stepped (Figure 6).

We backstripped our measured $F$ profile, using a range of $\phi_{0}$ and $\lambda$ parameter values, to define an envelope bounding FO (Figure 6; Supplementary Table 3). Our backstripped $F 0$ envelope mirrors the geometry of the measured $F$ profile, but has a greater magnitude (Figure 6). For example, backstripping suggests the maximum $F 0$ is between $\sim 112-205 \mathrm{~m}$, which is $\sim 2-$ $95 \mathrm{~m}$ greater than $F$ (Figure 6); these values suggest the maximum $F 0$ was less than the maximum $S T$ by $\sim 57 \pm 7 \%$ to $21 \pm 7 \%$. Across most of the fold there is an overlap between $S T$ and $F 0$ envelopes, although $T$ in the eastern section of the sill is locally greater than F0 (Figure 6). Where the Intra-Jurassic R2 horizon displays a synformal geometry above the eastern sill edge, the backstripped relief of the synform fold axis above the assumed pre-fold datum is $\sim 48-92 \mathrm{~m}$ and at Fault 1 it is $\sim 75-139 \mathrm{~m}$ (Figure 6).

\subsection{Fault characterisation}

Two fault populations are observed (Figure 4 and 5). Fault Population A comprises an array of N-to-NEstriking, low-to-high-throw normal faults primarily located within Triassic-to-Jurassic strata (Figure 4 and 5). Several faults within Population A offset the Base Cretaceous unconformity and extend upwards into the overlying sedimentary sequence (e.g. Figure 4B, C).
Fault Population A does not appear to offset the sill (Figure 4). Fault Population B is located primarily within the Early Cretaceous Barrow Group and Muderong Formation; faults within this population rarely extend below the Base Cretaceous Unconformity (e.g. Figure 4B, C). Faults within Fault Population B are closely spaced, have low-throws ( $\leq 25 \mathrm{~ms}$ TWT), a normal sense of motion, and are arranged in a polygonal pattern (Figure 4B, C, and 5E).

Fault 1 bounds the eastern edge of the sill and is part of Fault Population A (e.g. Figure 4B, C). There is a minor NNW-trending bend in Fault 1 where it is intersected in its hanging wall by a $\sim 3 \mathrm{~km}$ long, NW-dipping splay fault (Figure 5). A $T-z$ analysis of Fault 1 reveals throw decreases upwards from $\sim 426 \mathrm{~ms}$ TWT at the Intra-Mungaroo horizon to $\sim 0.02 \mathrm{~ms}$ TWT at the Top Barrow, just below its upper tip (Figure 7A; Supplementary Table 4). Superimposed on this throw are three zones between (Figure 7A; Supplementary Table 4): (i) the Intra-Mungaroo and Top Triassic horizons, where the throw gradient (i.e. change in throw divided by change in depth) is relatively low $(\sim 0.49)$, (ii) the Top Triassic and Base Cretaceous Unconformity horizons, where the throw gradient is relatively high ( 1.59), and (iii) the Base Cretaceous unconformity and upper fault tip, where the throw gradient is again relatively low $(\sim 0.32)$. For the Intra-Mungarooto-Top Mungaroo strata, an expansion index of 1.59 suggests the sequence thickens across the fault (Figure 7A; Supplementary Table 5). However, this expansion index does not consider the thickness of the sill emplaced within the hanging wall portion of the Intra-Mungaroo-to-Top Mungaroo strata; if sill thickness is accounted for, the true expansion index for this unit is 1.04 (Figure 7A). The expansion index for the Top Mungaroo-to-Top Triassic, which should be considered a minimum estimate because the Top Triassic is eroded in the footwall and the basin was sedimentstarved during this period, is 1.61 (Figure 7A; Supplementary Table 5). We cannot calculate an expansion index for Intra-Jurassic R1-to-Intra-Jurassic R2 or IntraJurassic R2-to-Base Cretaceous unconformity strata because these horizons are not present in the footwall (e.g. Figure 4B and 7A). Above the Base Cretaceous unconformity, expansion indices are $<1.26$ (Figure 7A; Supplementary Table 5).

A $T-x$ analysis of the Top Mungaroo horizon also demonstrates how the sill affects how throw varies along strike of Fault 1 (Figure 7B; Supplementary Table 6). For example, the maximum present-day throw is $\sim 606 \mathrm{~m}$, but when the sill thickness is accounted for (i.e. we remove the sill and thus shift overlying hanging wall horizons downwards), throw increases to $\sim 825 \pm 22 \mathrm{~m}$ (Figure 7B; Supplementary Table 6). The prominent throw minimum (present-day throw of $\sim 269 \mathrm{~m}$ ) on Fault 1, which disrupts the overall bellshaped morphology of the $T-x$ profile, is spatially coincident with the branch-point of the NE-SW striking 


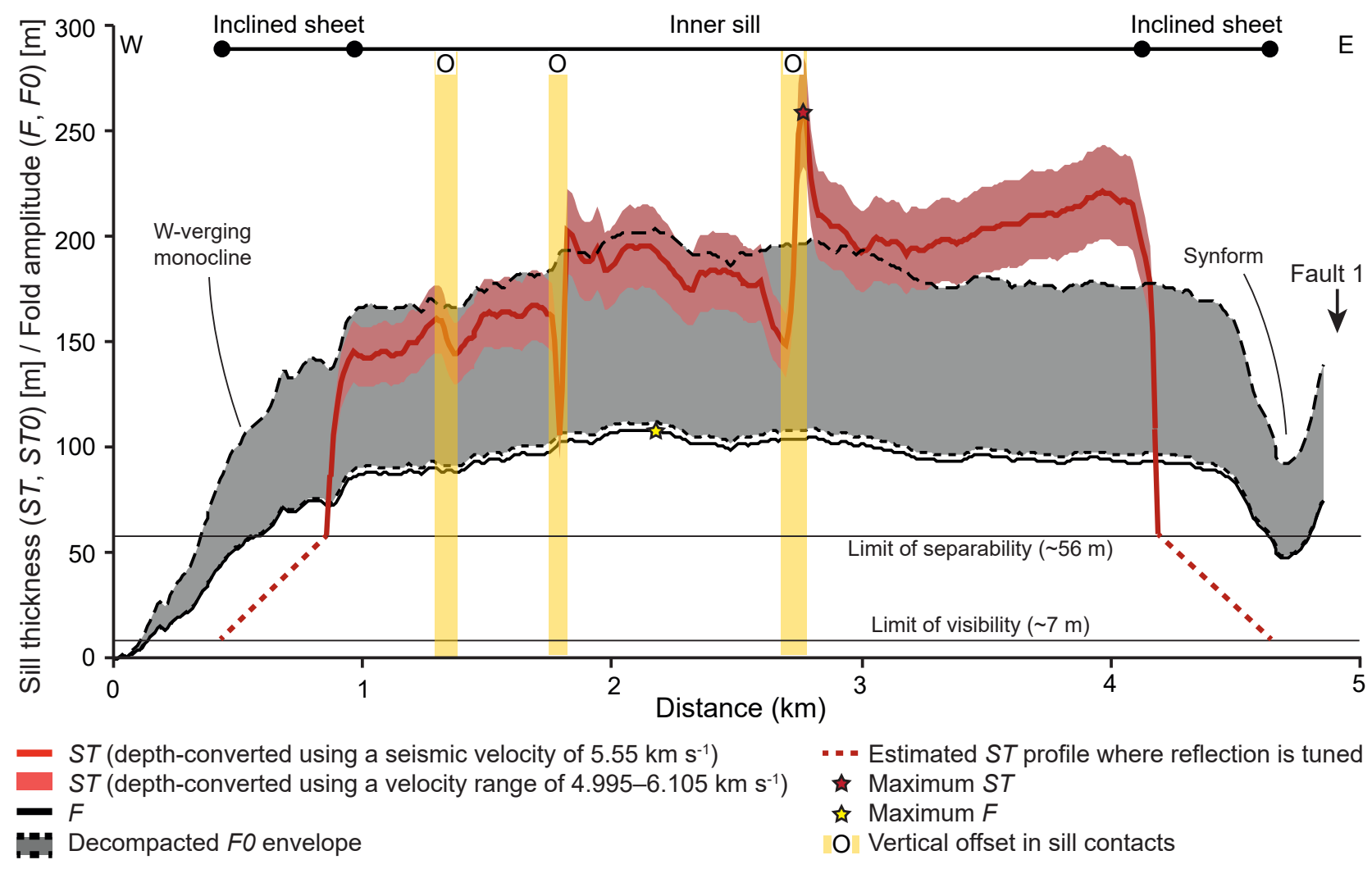

Figure 6: Plot of sill thickness and fold amplitude changes across the seismic line shown in Figure 4D. Sill thickness $(S T)$ is assumed to equal the original sill thickness $(S T 0)$ and its measurements in time have been depthconverted to metres assuming a seismic interval velocity of $\sim 5.550 \pm 0.555 \mathrm{~km} \mathrm{~s}^{-1}$. Sill thickness was only measured across the inner sill where a distinct Base Sill horizon can be mapped (e.g. Figure 4D-F). The thickness of the inclined sill limbs, which appear as tuned reflection packages in the seismic data, can only be defined as being between the limits of separability and visibility. The present-day fold amplitude $(F)$ was measured in time and converted using borehole-constrained seismic velocities. We decompacted and backstripped $F$ using a range of parameters to estimate the possible original fold amplitude $(F 0)$, which we display as an envelope.

hanging wall splay (Figure 7B; Supplementary Table 6). To the south of the studied sill, where Fault 1 has no intrusion in its hanging wall, there is an abrupt reduction in throw to $\sim 200 \mathrm{~m}$ (Figure 7B).

\section{Discussion}

\subsection{Sill geometry}

Like many sills observed in the field, imaged in seismic reflection data, or produced in physical or numerical models, the sill studied here comprises a broadly strata-concordant inner sill partly bounded by transgressive, inclined limbs (Figure 4); i.e. the sill has a saucer-shaped morphology [e.g. Galland et al. 2009; Hansen and Cartwright 2006; Malthe-Sørenssen et al. 2004; Polteau et al. 2008; Thomson and Hutton 2004]. The inner sill itself can be further sub-divided into several zones separated by transgressive, vertical offsets along its upper and lower contacts (Figure 4C). These offsets appear to radiate out from a focal area coinci- dent with the western portion of the NE-trending fault splay connected to Fault 1 (Figure 4C). Strata immediately above and below the offset sill contacts are typically continuous and not themselves offset (Figure 4DF), indicating the offset sill contacts probably do not arise due to seismically imaged faulting. Similar nonfault-related vertical offsets have been observed within sills and are interpreted to form when the leading edge of a sheet intrusion splits into discrete sections that exploit and propagate along different stratigraphic or structural levels [see Magee et al. 2019b]. The long axes of these vertical offsets parallel the sheet propagation axis and can thus provide a record of where magma was fed into the growing sill [see Magee et al. 2019b, and references therein]. If the vertical offset sill contacts we observe across the inner sill formed during and reflect sheet propagation, their radial disposition about a focal area may suggest magma was fed into the sill from a near point-like source (Figure 4C). Feeding of the sill from a near point-like source seemingly contradicts suggestions that elongate sills, such as the one 

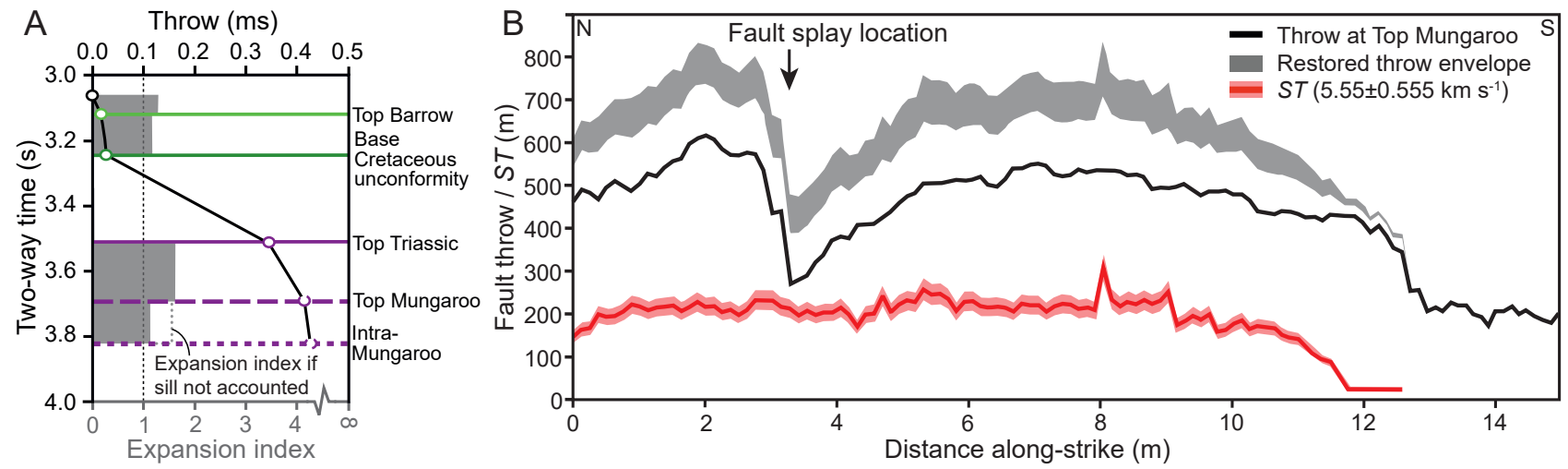

Figure 7: [A] Throw-depth $(T-z)$ plot compiling measurements from all horizons observed in both the hanging wall and footwall of Fault 1 along the seismic section in Figure 4B. Expansion indices for each interval are also shown. [B] Throw-length plot $(T-x)$ for Fault 1 measured along the Top Mungaroo horizon, compared to the along-strike variation in sill thickness $(S T)$ where it abuts the fault. We restore the pre-intrusion throw profile by removing the effects of the sill thickness, assuming the sill has a seismic velocity of $\sim 5.550 \pm 0.555 \mathrm{~km} \mathrm{~s}^{-1}$.

studied here, are fed from a fissure-like, possibly dykerelated source [e.g. Goulty and Schofield 2008]. To further investigate the controls on sill geometry, we first need to establish when it was emplaced relative to riftrelated faulting and intrusion of the underlying dyke recognised by Magee and Jackson [2020] (Figure 2A).

5.2 Timing of fault formation, folding, and sill emplacement

Thickening and divergence of Upper Triassic-to-Lower Cretaceous hanging wall strata towards Fault 1 indicate it was active and surface-breaking during the Late Triassic-to-Early Cretaceous (Figure 4D-F, 5, and 7A) [e.g. Jackson et al. 2017]. There are upward reductions in throw gradient and expansion indices at the Base Cretaceous unconformity, which we interpret to mark a reduction in strain rate across Fault 1 prior to deposition of the Barrow Group (Figure 4D-F and 7A) [see also Lathrop et al. 2020]. Footwall degradation during formation of the Base Cretaceous unconformity means we cannot determine whether this reduction in strain rate locally involved a period fault cessation or not [e.g. Magee et al. 2015]; however, kinematic analyses of syn-sedimentary faults elsewhere in the Glencoe 3D seismic survey, where little or no footwall degradation occurred, suggest faulting may have been continuous during formation of the Base Cretaceous unconformity [Lathrop et al. 2020].

The top of the supra-sill fold we mapped coincides with Intra-Jurassic R2 and is onlapped by Jurassic strata beneath the Base Cretaceous unconformity (Figure 4D, $\mathrm{E}$, and $5 \mathrm{C}$ ). Onlapping of strata onto the fold indicates Intra-Jurassic R2 represented the surface during deformation [Trude et al. 2003]. We interpret that folding occurred in response to sill emplacement and, at least partially, accommodated the intruding magma volume because: (i) strata adjacent to the fold, or beneath the sill, are not folded (e.g. Figure 4D-F), indicating deformation was not driven by regional horizontal shortening but instead by a localised, underlying, forcing process [i.e. it is a forced fold; Stearns 1978]; (ii) folding was not related to upwards fault propagation [e.g. Hardy and Finch 2006], as expansion indices reveal Fault 1 was surface-breaking in the Late Triassic-to-Jurassic, prior to and likely during sill emplacement (Figure 7A); and (iii) the lateral edge of the fold broadly overlies that of the sill (e.g. Figure 4D-F and 5B) [e.g. Magee et al. 2019a]. We also recognise depressions above the sill along Intra-Jurassic R2, which are infilled by overlying strata and underlain by pipes that extend down to the sill, suggesting these correspond to hydrothermal or volcanic vents related to magma emplacement and fluid escape (Figure 5) [e.g. Hansen 2006; Jamtveit et al. 2004; Planke et al. 2005]. By decompacting and backstripping the sill overburden, we estimate sill emplacement occurred in the Jurassic at a depth of $\sim 0.9 \mathrm{~km}$. Other intrusion-induced forced folds identified within the North Carnarvon Basin have been dated to the Kimmeridgian, and we consider the sill-fold pair studied here are likely a similar age [e.g. Magee et al. 2013b; Magee et al. 2017]. A Kimmeridgian age for sill emplacement would imply that the interpreted underlying dyke, which likely intruded in the Tithonian [Magee and Jackson 2020], probably does not represent the sill feeder.

\subsection{Sill emplacement and forced fold mechanics}

If roof uplift solely accommodates intrusion, we may expect the volume and amplitude of ground deformation to be broadly equivalent to, and thus a proxy for, the emplaced magma volume and thickness (e.g. Figure 3A) [e.g. Bunger and Cruden 2011; Hansen and Cartwright 2006; Jackson et al. 2013; Pollard and Johnson 1973; Stearns 1978]. For example, if the deform- 
ing overburden has no flexural strength, there should be no uplift beyond the intrusion edge [e.g. Hansen and Cartwright 2006; Magee et al. 2019a]. Although inversion of geodetic data that capture ground deformation above intrusions can produce reasonable estimates of emplaced magma volumes by assuming the crust behaves elastically [e.g. Pritchard and Simons 2004; Sigmundsson et al. 2020], the geometry of modelled intrusions is typically oversimplified compared to natural examples [Galland 2012]. Furthermore, field, modelling-, and seismic-based studies demonstrate that viscoelastic and/or plastic deformation of the overburden may accompany and generate space for magma emplacement (e.g. Figure 3B) [e.g. Magee et al. 2013b; Magee et al. 2019a; Morgan et al. 2008; Schofield et al. 2012; Sigmundsson et al. 2020]. For example, damage, porosity reduction, and faulting of the host rock can occur during bending [e.g. Magee et al. 2017; Morgan et al. 2008]. In addition to roof uplift, if other deformation processes accommodate intrusion, the volume of ground deformation will underestimate the intruded magma volume [Galland 2012]. To determine the structure of syn-emplacement ground deformation above our studied sill, we depth-converted and decompacted the top surface of the folded sequence and compare its amplitude to sill thickness (Figure 6). We note we cannot determine whether lateral variations in compaction degree have modified the fold shape; i.e. the true $F 0$ profile could realistically describe any pattern within the defined envelope.

Where the western limb of the fold overlies a stratabound inclined sheet in the south of the study area, the sill is overlain by a relatively smooth, monoclinal fold containing little evidence for brittle deformation (Figures 4 and 6). Over the western half of the sill and across this monocline, there is a broad overlap between the estimated sill thickness $(S T)$ and the flat-topped, syn-emplacement surface relief (fold amplitude F0) (Figure 6). These relationships between sill and restored overburden geometry imply that space for the intruding magma was primarily generated by roof uplift, which itself was facilitated by the localisation of host rock damage (folding) above the western sill termination [e.g. Got et al. 2019]. We also note that the monoclinal fold has a present-day relief of $\sim 50 \mathrm{~m}$ above the resolved western sill tip and appears to extend beyond the mapped edge of the sill (Figure 4D and 6). The maximum $S T$ of the western inclined sill limb, which is defined by the limit of separability $(56.0 \pm 5.6 \mathrm{~m})$, is also less than the predicted $F 0$ range of the overlying fold (Figure 6). These sill-fold relationships suggest: (i) the deformed strata likely had some flexural strength, meaning our decompaction method underestimates $F 0$ [e.g. Hansen and Cartwright 2006; Magee et al. 2019a], and (ii) the true sill edge is unresolved in our data.

Similar to the western side of the sill, the present-day minimum relief of the fold at Intra-Jurassic R2 above the eastern edge of the fault-hosted inclined sheet is $\sim 47 \mathrm{~m}$ (i.e. the synformal fold axis); this corresponds to an estimated decompacted relief of $\sim 48-92 \mathrm{~m}$ (Figure 6; Supplementary Table 3). The amplitude of this eastern fold is also greater than the potential maximum $S T$ of the underlying inclined sheet, which is expressed in the data as a tuned reflection package (Figure $4 \mathrm{~B}$ and 6); however, this eastern fold limb has a synformal geometry, with a half-width of $\sim 160 \mathrm{~m}$, and is upturned immediately adjacent to Fault 1 . Here, the synform has a present-day relief of $\sim 75 \mathrm{~m}$, which corresponds to an estimated decompacted relief of $\sim 75-139 \mathrm{~m}$ (Figure 6; Supplementary Table 3); i.e. F0 does not decay to zero as is observed at the western sill limb (Figure 6). Furthermore, we show that towards this eastern limb, the estimated range of $S T$ is broadly greater than $F 0$ (Figure 6), although we acknowledge our decompaction analysis likely underestimates $F 0$ as the folded section probably had flexural strength. We consider two scenarios that could produce the observed sill-fold relationships immediately adjacent to Fault 1: (i) projecting the eastward-dipping synform limb down-dip suggests $F 0$ may have decayed to zero at Fault 1 (i.e. the fold was a monocline, similar to that defining the western limb), implying the upturned part of the fold limb could have been generated post-folding due to normal faulting (i.e. frictional fault drag; Figure 8A), or (ii) the synform was generated by collapse of strata during fluid escape via a pipe emanating from the sill tip (Figure 8B), similar to hydrothermal vents observed elsewhere [e.g. Hansen 2006; Jamtveit et al. 2004; Planke et al. 2005]. We discount the frictional fault drag mechanism because the synform shape and magnitude is inconsistent with fault dip [i.e. it is not low-angle; Grasemann et al. 2005] or geometry [i.e. it does not comprise underlapping segments; Childs et al. 2016] (Figure 4D, E). Instead we favour a fluid escape origin for the synform, which implies there may have been no prominent monoclinal limb formed above the eastern sill edge (Figure 8B). We suggest the potential absence of a monoclinal limb above the eastern edge of the sill could be because uplift was facilitated by inversion (i.e. reverse reactivation) of Fault 1, as opposed to folding (Figure 8B). Such uplift and reverse reactivation of normal faults has been recognised to have helped accommodate sill and inclined sheet emplacement in the Franklin Sills, Canada [Bédard et al. 2012]. The local disparity between $F 0$ and $S T$ adjacent to Fault 1 (Figure 6) implies compaction of overburden strata may also have contributed to accommodating sill emplacement [Jackson et al. 2013; Magee et al. 2013b; Magee et al. 2019a].

Overall, we suggest sill emplacement can be broadly described by a three-stage model: (i) emplacement of a thin, layer-parallel sill containing intrusive steps [Magee et al. 2019b], which spreads laterally with little or no roof uplift (Figure 9A) [e.g. Hansen and Cartwright 2006; Kavanagh et al. 2015; Magee et al. 2013b; Pollard and Johnson 1973; Wilson et al. 2016], (ii) sill inflation, which drove roof uplift and ground 


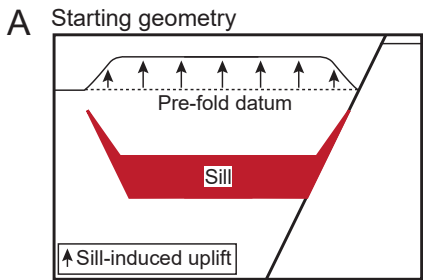

B
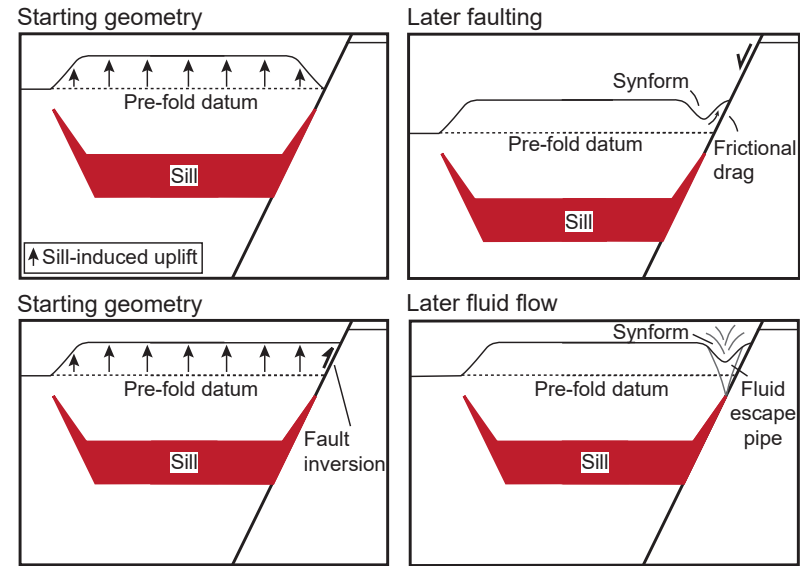

Later fluid flow

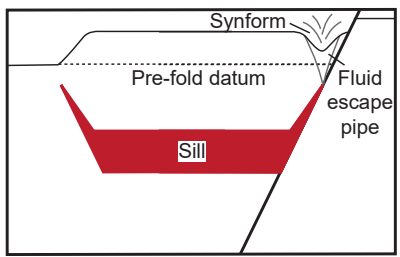

Figure 8: $[A]$ Schematics showing how the synform along Intra-Jurassic R2 may be generated adjacent to Fault 1 in response to normal fault frictional drag. The fold initially extends beyond the limit of the sill and, as subsequent fault slip occurs, the fault-adjacent part of the monoclinal limb is rotated producing a synform with an axis overlying the sill tip. [B] Schematics showing how the synform along Intra-Jurassic R2 may be generated adjacent to Fault 1 by fluid expulsion from the sill tip and/or surrounding strata. In this model, there is no original monoclinal fold above the sill tip.

deformation, accommodated by folding above the western part of the sill and localised inversion of Fault 1 and overburden compaction above its eastern part (Figure 4D, 6, and 9B) [Bédard et al. 2012; Bunger and Cruden 2011; Galland and Scheibert 2013; Goulty and Schofield 2008; Magee et al. 2017; Montanari et al. 2017], and (iii) transgression of inclined sheets, which likely exploited fold-related outer-arc extensional fractures or fault opening of Fault 1, and perhaps fluid escape (Figure 4D-F, 6, and 9C) [e.g. Bédard et al. 2012; Magee et al. 2013a; Siregar et al. 2019; Thomson and Schofield 2008]. Subsequent burial-related compaction has modified the forced fold, by reducing its amplitude ( $F 0$ becomes $F$ ), but not the thickness of the incompressible sill (Figure 9D) [e.g. Magee et al. 2019a]. Our work confirms that the presence of pre-existing faults can, at least partly, control intrusion-induced deformation and provide pathways for magma ascent [e.g. Bédard et al. 2012; Gaffney et al. 2007; Magee et al. 2013a; Valentine and Krogh 2006]. Furthermore, we suggest that opening of Fault 1 and uplift of its hanging wall strata favoured the southwards propagation of the sill, thereby producing its elongate geometry.

5.4 Implications for the geometric and kinematic analysis of normal faults

Variations in throw (and displacement) across segmented normal faults is commonly interpreted to reflect their kinematics [e.g. Ferrill and Morris 2001;
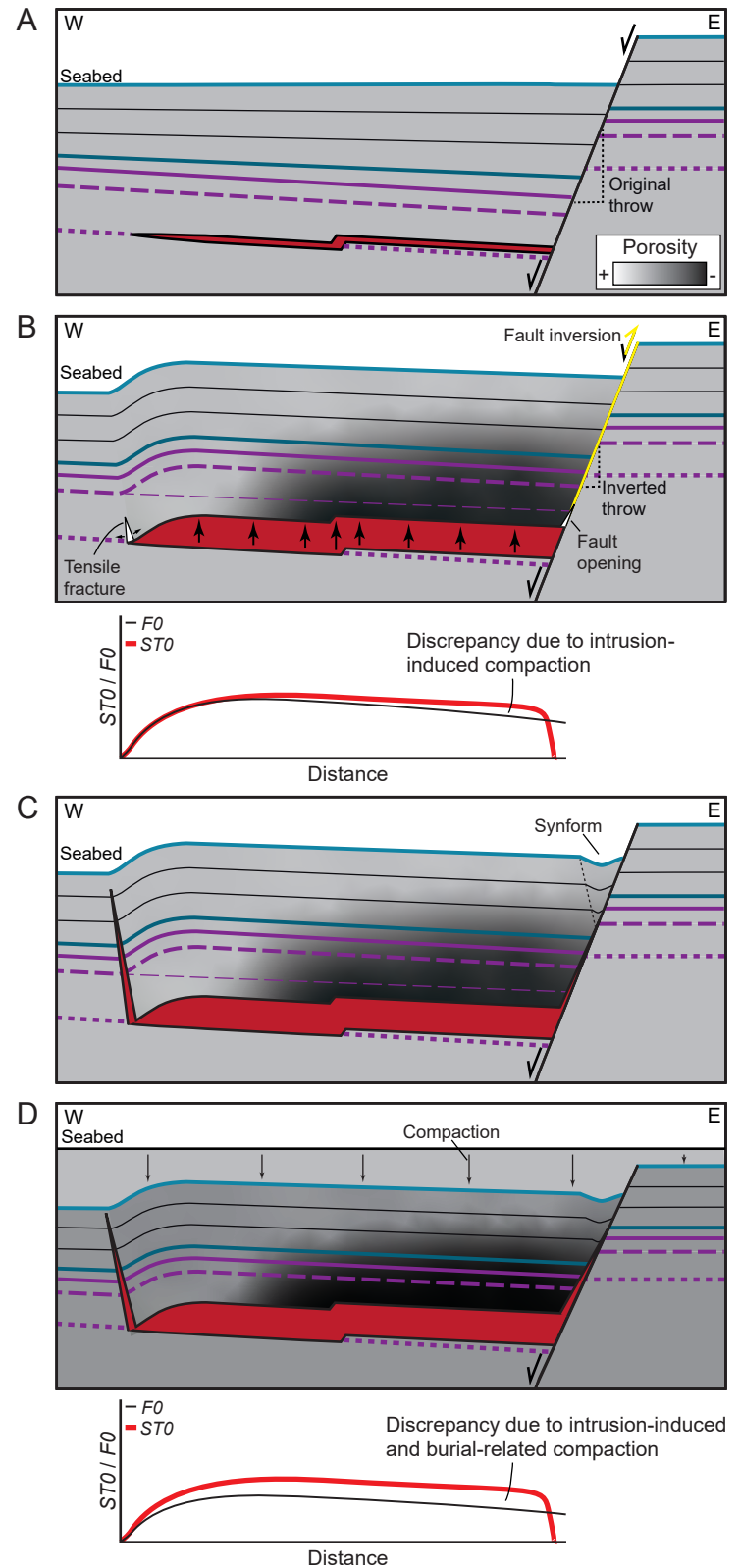

Figure 9: Conceptual model of inner sill and inclined sheet emplacement. [A] Intrusion and lateral propagation of a thin sill [e.g. Hansen and Cartwright 2006; Kavanagh et al. 2015; Magee et al. 2013b; Pollard and Johnson 1973; Wilson et al. 2016]. [B] Inflation of the sill causes uplift of the overburden by folding, particularly above the western part of the sill, and inversion of the pre-existing fault. Heterogeneous vertical compaction of the overburden also likely accommodates magma emplacement, causing a discrepancy in between $S T$ and $F 0$ above the eastern part of the sill. Tensile fractures may open due to outer-arc stretching during folding and where the fault plane is opened [Bunger and Cruden 2011; Galland and Scheibert 2013; Goulty and Schofield 2008; Magee et al. 2017; Montanari et al. 2017]. [C] Magma exploits open fractures, forming inclined sill limbs [e.g. Bédard et al. 2012; Magee et al. 2013a; Siregar et al. 2019; Thomson and Schofield 2008]. [D] Burial-related compaction reduces the forced fold amplitude but not sill thickness [e.g. Magee et al. 2019a].

Page 14 
Hongxing and Anderson 2007; Needham et al. 1996; Peacock and Sanderson 1991; Reilly et al. 2015; Robson et al. 2016; Rotevatn et al. 2019; Tvedt et al. 2013; Walsh et al. 2003; Walsh and Watterson 1989; Watterson 1986]. For example, numerical modelling shows the location of throw maxima may coincide with the nucleation site of faults [e.g. Deng et al. 2017]. Recognition of multiple throw maxima across faults have therefore been related to the nucleation, growth, and eventual coalescence of initially isolated fault segments; in these interpretations, throw minima are inferred to represent sites of segment linkage (e.g. relay zones) [e.g. Cartwright et al. 1996; Jackson and Rotevatn 2013; Mansfield and Cartwright 1996; Peacock and Sanderson 1991; Trudgill and Cartwright 1994]. Our work supports previous suggestions that sill emplacement, roof uplift, and ground deformation in the immediate hanging wall of a fault can drive its inversion (Figure 8B) [Bédard et al. 2012; Magee et al. 2013b]. To demonstrate the effect such intrusion-induced inversion can have on the distribution of fault throw, we restored the original throw pattern along Fault 1 by removing the depth-converted thickness of the sill (Figure $7 \mathrm{~B}$ ). We show that Fault 1 was inverted by $\sim 15-$ $310 \mathrm{~m}$, locally producing zones of lower throw and higher throw gradients (Figure 7B). In extreme cases, where sill thickness exceeds the pre-intrusion throw on a fault, we envisage that intrusion-induced inversion could locally cause the fault to display a reverse motion. Correctly identifying where intrusion-induced inversion may have modified fault throw is critical to interpreting the kinematic history of a fault. Identification of intrusion-induced inversion is likely relatively simple where sills have a clear seismic expression and their geometrical relationship to faults can be defined. However, recent studies have shown that an abundance of sills with thicknesses below the limit of visibility of a seismic reflection dataset may not be recognised in the data but can cumulatively over-thicken a sedimentary sequence [e.g. Mark et al. 2019; Schofield et al. 2017]. If the degree of over-thickening by sills with thickness below the data resolution varies across (as well as along) a fault, the throw (and displacement) distribution on the latter will be modified and poorly reflect its preintrusion geometry and kinematic history.

Thickening of stratigraphic packages intruded by sills may also modify expansion indices calculated across a fault. For example, in the south of our study area, the expansion index calculated between an IntraMungaroo and Top Mungaroo is 1.59 (Figure 7A); typically this value, which is $>1$, would be interpreted to indicate the fault was active and surface-breaking during deposition of this sedimentary sequence [e.g. Jackson et al. 2017]; however, if we remove the thickness of the sill, then the expansion index approaches 1 (Figure 7A). Thickness of intrusive bodies should thus be excluded from analysed of expansion indices, as failure to do so may lead to errors when determining the growth history of normal faults.

\section{Conchusions}

Understanding the translation of magma emplacement into ground deformation is critical to volcano monitoring, which partly relies on the inversion of surface uplift data to model intrusion geometries, locations, and volumes. Such inversions assume ground deformation occurs purely via elastic deformation, but there is a growing consensus that viscoelastic and/or plastic processes may also generate space for intruding magma. Using seismic reflection data from offshore NW Australia, we investigate the form of a forced fold developed above a saucer-shaped sill in the Late Jurassic. We show that folding broadly accommodated emplacement; i.e. sill thickness and fold amplitude are equal across the western half of the sill. However, adjacent to a major pre-existing fault, fold amplitude is less than sill thickness, suggesting space for the sill was locally generated by a combination of fault inversion and overburden compaction. Our results suggest that the presence of pre-existing faults can modify and complicate space generation for shallow-level intrusions, causing the true geometry and location of magma bodies to deviate from the shape and site of their surface expression. Furthermore, we demonstrate that intrusioninduced fault inversion: (i) allowed magma to ascend up the fault, and (ii) modified the displacement distribution of the fault. Given fault displacement is commonly used to unravel fault kinematics, and thereby tectonic histories, caution should be applied when interpreting fault displacement in areas where thin sills below the resolution of seismic reflection data may be present.

\section{Author contributions}

JN conducted the analysis and interpretation, wrote the first paper draft, and helped edit the manuscript. $\mathrm{CM}$ wrote the manuscript and contributed to analysis and interpretation. CALJ and JK contributed to interpretation and manuscript editing. BL contributed to manuscript editing and understanding of the regional fault setting.

\section{Acknowledgements}

We are grateful to Geoscience Australia for provision of the seismic reflection and borehole data. We also thank Schlumberger for use of Petrel seismic interpretation software. We thank Steffi Burchardt and Jean-Luc Got for their excellent reviews, and Jamie Farquharson for editorial handling. 


\section{Data AVAilability}

The seismic reflection and borehole data is publicly available from https://www.ga.gov.au/nopims. Supplementary Tables 1-6 are provided alongside the online version of this article.

\section{COPYRight NOTICE}

(C) The Author(s) 2021. This article is distributed under the terms of the Creative Commons Attribution 4.0 International License, which permits unrestricted use, distribution, and reproduction in any medium, provided you give appropriate credit to the original author(s) and the source, provide a link to the Creative Commons license, and indicate if changes were made.

\section{REFERENCES}

Baudon, C. and J. Cartwright (2008). "The kinematics of reactivation of normal faults using high resolution throw mapping". Journal of Structural Geology 30.8, pp. 1072-1084. Dor: 10.1016/j.jsg.2008.04.008.

Bédard, J. H., H. R. Naslund, P. Nabelek, A. Winpenny, M. Hryciuk, W. Macdonald, B. Hayes, K. Steigerwaldt, T. Hadlari, R. Rainbird, K. Dewing, and E. Girard (2012). "Fault-mediated melt ascent in a Neoproterozoic continental flood basalt province, the Franklin sills, Victoria Island, Canada". Geological Society of America Bulletin 124.5-6, pp. 723-736. Dor: 10.1130/b30450.1.

Biggs, J., E. Y. Anthony, and C. J. Ebinger (2009). "Multiple inflation and deflation events at Kenyan volcanoes, East African Rift". Geology 37.11, pp. 979-982. Dor: $10.1130 / \mathrm{g} 30133 \mathrm{a} .1$.

Biggs, J., I. D. Bastow, D. Keir, and E. Lewi (2011). "Pulses of deformation reveal frequently recurring shallow magmatic activity beneath the Main Ethiopian Rift". Geochemistry, Geophysics, Geosystems 12.9. DoI: $10.1029 / 2011 \mathrm{gc} 003662$.

Bilal, A., K. McClay, and N. Scarselli (2018). "Faultscarp degradation in the central Exmouth Plateau, North West Shelf, Australia". Geological Society, London, Special Publications, SP476.11. DoI: $10.1144 /$ sp476.11.

Black, M., K. D. McCormack, C. Elders, and D. Robertson (2017). "Extensional fault evolution within the Exmouth Sub-basin, North West Shelf, Australia". Marine and Petroleum Geology 85, pp. 301-315. DoI: 10.1016/j . marpetgeo. 2017.05.022.

Bunger, A. P. and A. R. Cruden (2011). "Modeling the growth of laccoliths and large mafic sills: Role of magma body forces". Journal of Geophysical Research 116.B2. DoI: $10.1029 / 2010$ jb007648.

Cannavò, F., A. G. Camacho, P. J. González, M. Mattia, G. Puglisi, and J. Fernández (2015). "Real
Time Tracking of Magmatic Intrusions by means of Ground Deformation Modeling during Volcanic Crises". Scientific Reports 5.1. Dor: 10 . 1038 / srep10970.

Caricchi, L., J. Biggs, C. Annen, and S. Ebmeier (2014). "The influence of cooling, crystallisation and remelting on the interpretation of geodetic signals in volcanic systems". Earth and Planetary Science Letters 388, pp. 166-174. Dor: 10.1016/j . eps1.2013.12.002.

Cartwright, J., R. Bouroullec, D. James, and H. Johnson (1998). "Polycyclic motion history of some Gulf Coast growth faults from high-resolution displacement analysis". Geology 26.9, p. 819. Dor: 10.1130/ $0091-7613$ (1998) $026<0819$ : pmhosg>2. 3. co; 2 .

Cartwright, J. A., C. Mansfield, and B. Trudgill (1996). "The growth of normal faults by segment linkage". Geological Society, London, Special Publications 99.1, pp. 163-177. DoI: 10.1144/gsl.sp.1996.099.01.13.

Cartwright, J. A., B. D. Trudgill, and C. S. Mansfield (1995). "Fault growth by segment linkage: an explanation for scatter in maximum displacement and trace length data from the Canyonlands Grabens of SE Utah". Journal of Structural Geology 17.9, pp. 1319-1326. DoI: 10.1016/0191-8141(95) 00033-a. Castro, J. M., B. Cordonnier, C. I. Schipper, H. Tuffen, T. S. Baumann, and Y. Feisel (2016). "Rapid laccolith intrusion driven by explosive volcanic eruption". $\mathrm{Na}$ ture Communications 7.1. DoI: 10.1038/ncomms 13585.

Chaussard, E. (2016). "Subsidence in the Parícutin lava field: Causes and implications for interpretation of deformation fields at volcanoes". Journal of Volcanology and Geothermal Research 320, pp. 1-11. Dor: 10. 1016/j . jvolgeores. 2016.04.009.

Childs, C., T. Manzocchi, A. Nicol, J. J. Walsh, A. M. Soden, J. C. Conneally, and E. Delogkos (2016). "The relationship between normal drag, relay ramp aspect ratio and fault zone structure". Geological Society, London, Special Publications 439.1, pp. 355-372. DoI: 10.1144/sp439.16.

Childs, K., J. Banfield, M. Jakymec, and A. Jones. (2013). Well Completion Report: Chester-1 E Chester-1 ST1 interpretative data. National Offshore Petroleum Information Management System. Hess Exploration Australia Pty Limited. [dataset].

De Saint-Blanquat, M., G. Habert, E. Horsman, S. S. Morgan, B. Tikoff, P. Launeau, and G. Gleizes (2006). "Mechanisms and duration of non-tectonically assisted magma emplacement in the upper crust: The Black Mesa pluton, Henry Mountains, Utah". Tectonophysics 428.1-4, pp. 1-31. Dor: $10.1016 / \mathrm{j}$. tecto.2006.07.014.

Deng, C., R. L. Gawthorpe, E. Finch, and H. Fossen (2017). "Influence of a pre-existing basement weakness on normal fault growth during oblique extension: Insights from discrete element modeling". Journal of Structural Geology 105, pp. 44-61. Dor: 10.1016/ j.jsg.2017.11.005. 
Direen, N. G., H. M. J. Stagg, P. A. Symonds, and J. B. Colwell (2008). "Architecture of volcanic rifted margins: new insights from the Exmouth - Gascoyne margin, Western Australia". Australian Journal of Earth Sciences 55.3, pp. 341-363. DoI: 10.1080/ 08120090701769472 .

Driscoll, N. W. and G. D. Karner (1998). "Lower crustal extension across the Northern Carnarvon basin, Australia: Evidence for an eastward dipping detachment". Journal of Geophysical Research: Solid Earth 103.B3, pp. 4975-4991. DOI: 10.1029/97jb03295.

Ebmeier, S. K. et al. (2018). "Synthesis of global satellite observations of magmatic and volcanic deformation: implications for volcano monitoring \& the lateral extent of magmatic domains". Journal of Applied Volcanology 7.1. DoI: 10.1186/s13617-018-0071-3.

Eide, C. H., N. Schofield, I. Lecomte, S. J. Buckley, and J. A. Howell (2017). "Seismic interpretation of sill complexes in sedimentary basins: implications for the sub-sill imaging problem". Journal of the Geological Society 175.2, pp. 193-209. Dor: 10.1144/jgs2017096.

Exon, N., B. Haq, and U. Von Rad (1992). "Exmouth Plateau revisited: scientific drilling and geological framework". Proceedings of the Ocean Drilling Program, Scientific Results, 122, pp. 3-20.

Ferrill, D. A. and A. P. Morris (2001). "Displacement gradient and deformation in normal fault systems". Journal of Structural Geology 23.4, pp. 619-638. Dor: 10.1016/s0191-8141(०0) $00139-5$.

Frey, Ø., S. Planke, P. A. Symonds, and M. Heeremans (1998). "Deep crustal structure and rheology of the Gascoyne volcanic margin, western Australia". Marine Geophysical Researches 20.4, pp. 293-311. DoI: 10.1023/a: 1004791330763.

Gaffney, E. S., B. Damjanac, and G. A. Valentine (2007). "Localization of volcanic activity: 2. Effects of preexisting structure". Earth and Planetary Science Letters 263.3-4, pp. 323-338. Dor: 10.1016/j .eps1.2007.09. 002.

Galland, O. and J. Scheibert (2013). "Analytical model of surface uplift above axisymmetric flat-lying magma intrusions: Implications for sill emplacement and geodesy". Journal of Volcanology and Geothermal Research 253, pp. 114-130. Dor: $10.1016 / \mathrm{j}$. jvolgeores.2012.12.006.

Galland, O. (2012). "Experimental modelling of ground deformation associated with shallow magma intrusions". Earth and Planetary Science Letters 317-318, pp. 145-156. DoI: 10.1016/j .epsl.2011.10.017.

Galland, O., S. Planke, E.-R. Neumann, and A. MaltheSørenssen (2009). "Experimental modelling of shallow magma emplacement: Application to saucershaped intrusions". Earth and Planetary Science Letters 277.3-4, pp. 373-383. DOI: $10.1016 / \mathrm{j}$. epsl . 2008.11 .003$.
Gartrell, A., J. Torres, M. Dixon, and M. Keep (2016). "Mesozoic rift onset and its impact on the sequence stratigraphic architecture of the Northern Carnarvon Basin”. The APPEA Journal 56.1, p. 143. Dor: 10.1071/ aj 15012 .

Gibbons, A. D., U. Barckhausen, P. van den Bogaard, K. Hoernle, R. Werner, J. M. Whittaker, and R. D. Müller (2012). "Constraining the Jurassic extent of Greater India: Tectonic evolution of the West Australian margin”. Geochemistry Geophysics Geosystems 13. Dor: 10 . 1029/2011gc003919.

Got, J.-L., D. Amitrano, I. Stefanou, E. Brothelande, and A. Peltier (2019). "Damage and Strain Localization Around a Pressurized Shallow-Level Magma Reservoir". Journal of Geophysical Research: Solid Earth 124.2, pp. 1443-1458. Dor: 10.1029/2018jb016407.

Goulty, N. and N. Schofield (2008). "Implications of simple flexure theory for the formation of saucershaped sills". Journal of Structural Geology 30.7, pp. 812-817. DOI: 10.1016/j.jsg.2008.04.002.

Grasemann, B., S. Martel, and C. Passchier (2005). "Reverse and normal drag along a fault". Journal of Structural Geology 27.6, pp. 999-1010. DoI: $10.1016 / \mathrm{j}$. jsg.2005.04.006.

Guldstrand, F., S. Burchardt, E. Hallot, and O. Galland (2017). "Dynamics of Surface Deformation Induced by Dikes and Cone Sheets in a Cohesive Coulomb Brittle Crust". Journal of Geophysical Research: Solid Earth 122.10, pp. 8511-8524. DoI: 10 . $1002 / 2017 \mathrm{jb} 014346$.

Hansen, D. M. (2006). "The morphology of intrusionrelated vent structures and their implications for constraining the timing of intrusive events along the NE Atlantic margin". Journal of the Geological Society 163.5, pp. 789-800. DOI: 10.1144 /0016-76492004167.

Hansen, D. M. and J. Cartwright (2006). "The threedimensional geometry and growth of forced folds above saucer-shaped igneous sills". Journal of Structural Geology 28.8, pp. 1520-1535. Dor: $10.1016 / \mathrm{j}$. jsg. 2006.04.004.

Hardy, S. and E. Finch (2006). "Discrete element modelling of the influence of cover strength on basementinvolved fault-propagation folding". Tectonophysics 415.1-4, pp. 225-238. DoI: $10.1016 / \mathrm{j}$. tecto . 2006 . 01.002 .

Hocking, R. (1992). Jurassic deposition in the southern and central North West Shelf. Western Australia: Geological Survey Western Australia Record 199217.

Hocking, R. M., H. T. Moors, and W. E. Van de Graaff (1987). Geology of the Carnarvon Basin, Western Australia. Vol. 133. Perth: State Print. Division. ISBN: 073091352X.

Hongxing, G. and J. K. Anderson (2007). "Fault Throw Profile and Kinematics of Normal Fault: Conceptual Models and Geologic Examples". Geological Journal of China Universities 13.1, pp. 75-88. 
Hopper, J. R., J. C. Mutter, R. L. Larson, and C. Z. Mutter (1992). "Magmatism and rift margin evolution: Evidence from northwest Australia". Geology 20.9, p. 853. DOI: $10.1130 / 0091-7613(1992) 020<0853$ : marmee $>2.3$. co; 2 .

Jackson, C. A.-L., N. Schofield, and B. Golenkov (2013). "Geometry and controls on the development of igneous sill-related forced folds: A 2-D seismic reflection case study from offshore southern Australia". Geological Society of America Bulletin 125.1112, pp. 1874-1890. DoI: 10.1130/b30833.1.

Jackson, C. A.-L., R. E. Bell, A. Rotevatn, and A. B. M. Tvedt (2017). "Techniques to determine the kinematics of synsedimentary normal faults and implications for fault growth models". Geological Society, London, Special Publications 439.1, pp. 187-217. Dor: 10.1144/ sp439.22.

Jackson, C. A.-L. and A. Rotevatn (2013). "3D seismic analysis of the structure and evolution of a saltinfluenced normal fault zone: A test of competing fault growth models". Journal of Structural Geology 54, pp. 215-234. DoI: 10.1016/j.jsg.2013.06.012.

Jamtveit, B., H. Svensen, Y. Y. Podladchikov, and S. Planke (2004). "Hydrothermal vent complexes associated with sill intrusions in sedimentary basins". Geological Society, London, Special Publications 234.1, pp. 233-241. Dor: 10.1144/gsl.sp.2004.234.01.15.

Johnson, A. M. and D. D. Pollard (1973). "Mechanics of growth of some laccolithic intrusions in the Henry mountains, Utah, I". Tectonophysics 18.3-4, pp. 261309. DOI: $10.1016 / 0040-1951$ (73) 90050-4.

Karner, G. D. and N. W. Driscoll (1999). "Style, timing and distribution of tectonic deformation across the Exmouth Plateau, northwest Australia, determined from stratal architecture and quantitative basin modelling". Geological Society, London, Special Publications 164.1, pp. 271-311. DoI: 10.1144/gsl.sp. 1999. 164.01 .14$.

Kavanagh, J. L., D. Boutelier, and A. R. Cruden (2015). "The mechanics of sill inception, propagation and growth: Experimental evidence for rapid reduction in magmatic overpressure". Earth and Planetary Science Letters 421, pp. 117-128. Dor: $10.1016 / \mathrm{j}$. epsl. 2015.03 .038 .

Lathrop, B., C. A.-L. Jackson, R. Bell, and A. Rotevatn (2020). "The kinematics of growth faults and the role of lateral tip retreat". DoI: 10.31223/osf.io/ueb7r.

Longley, I. M., C. Buessenschuett, L. Clydsdale, C. J. Cubitt, R. C. Davis, M. K. Johnson, N. M. Marshall, A. P. Murray, R. Somerville, T. B. Spry, and N. B. Thompson (2002). "The North West Shelf of Australia-A Woodside Perspective". The Sedimentary Basins of Western Australia. Ed. by M. Keep and S. J. Moss. The Petroleum Exploration Society of Australia, pp. 27-88.

Magee, C., C. A.-. L. Jackson, and N. Schofield (2013a). "The influence of normal fault geometry on igneous sill emplacement and morphology". Geology 41.4, pp. 407-410. DoI: 10.1130/g33824.1.

Magee, C., F. Briggs, and C. A.-L. Jackson (2013b). "Lithological controls on igneous intrusion-induced ground deformation". Journal of the Geological Society 170.6, pp. 853-856. DoI: 10.1144/jgs2013-029.

Magee, C., O. B. Duffy, K. Purnell, R. E. Bell, C. A.-L. Jackson, and M. T. Reeve (2015). "Fault-controlled fluid flow inferred from hydrothermal vents imaged in 3D seismic reflection data, offshore NW Australia". Basin Research 28.3, pp. 299-318. DoI: 10.1111/bre. 12111.

Magee, C., M. Hoggett, C. A.-L. Jackson, and S. M. Jones (2019a). "Burial-Related Compaction Modifies Intrusion-Induced Forced Folds: Implications for Reconciling Roof Uplift Mechanisms Using Seismic Reflection Data". Frontiers in Earth Science 7. Dor: 10.3389/feart.2019.00037.

Magee, C. and C. A.-L. Jackson (2020). "Seismic reflection data reveal the 3D structure of the newly discovered Exmouth Dyke Swarm, offshore NW Australia". DoI: $10.5194 / \mathrm{se}-2019-201$.

Magee, C., C. A.-L. Jackson, J. P. Hardman, and M. T. Reeve (2017). "Decoding sill emplacement and forced fold growth in the Exmouth Sub-basin, offshore northwest Australia: Implications for hydrocarbon exploration". Interpretation 5.3, SK11-SK22. DOI: 10.1190/int-2016-0133.1.

Magee, C., J. Muirhead, N. Schofield, R. J. Walker, O. Galland, S. Holford, J. Spacapan, C. A.-L. Jackson, and W. McCarthy (2019b). "Structural signatures of igneous sheet intrusion propagation". Journal of Structural Geology 125, pp. 148-154. DoI: $10.1016 / \mathrm{j}$. jsg.2018.07.010.

Magee, C. et al. (2018). "Magma Plumbing Systems: A Geophysical Perspective". Journal of Petrology 59.6, pp. 1217-1251. DOI: 10.1093/petrology/egy 064.

Malthe-Sørenssen, A., S. Planke, H. Svensen, and B. Jamtveit (2004). "Formation of saucer-shaped sills". Geological Society, London, Special Publications 234.1, pp. 215-227. DoI: 10.1144/gsl.sp.2004.234.01.13.

Mansfield, C. and J. Cartwright (1996). "High resolution fault displacement mapping from threedimensional seismic data: evidence for dip linkage during fault growth". Journal of Structural Geology 18.2-3, pp. 249-263. DoI: $10.1016 /$ s0191-8141(96) $80048-4$.

Mark, N. J., S. P. Holford, N. Schofield, C. H. Eide, S. Pugliese, D. A. Watson, and D. Muirhead (2019). "Structural and lithological controls on the architecture of igneous intrusions: examples from the NW Australian Shelf". Petroleum Geoscience 26.1, pp. 5069. DoI: $10.1144 /$ petgeo2018-067.

Marshall, N. and S. Lang (2013). "A new sequence stratigraphic framework for the North West Shelf, Australia". The Sedimentary Basins of Western Australia. Ed. by S. J. Moss and M. Keep. Vol. 4. The Petroleum Exploration Society of Australia. 
Moig, N. and S. Massie (2010). Well Completion Report, Rimfire-1, Interpretive data. National Offshore Petroleum Information Management System. Hess Exploration Australia Pty Limited. [dataset].

Montanari, D., M. Bonini, G. Corti, A. Agostini, and C. D. Ventisette (2017). "Forced folding above shallow magma intrusions: Insights on supercritical fluid flow from analogue modelling". Journal of Volcanology and Geothermal Research 345, pp. 67-80. DoI: 10 . 1016/j . jvolgeores . 2017.07.022.

Morgan, S., A. Stanik, E. Horsman, B. Tikoff, M. de Saint Blanquat, and G. Habert (2008). "Emplacement of multiple magma sheets and wall rock deformation: Trachyte Mesa intrusion, Henry Mountains, Utah". Journal of Structural Geology 30.4, pp. 491-512. Dor: 10.1016/j.jsg.2008.01.005.

Needham, D. T., G. Yielding, and B. Freeman (1996). "Analysis of fault geometry and displacement patterns". Geological Society, London, Special Publications 99.1, pp. 189-199. DoI: 10.1144/gsl.sp. 1996.099. 01.15 .

Nicol, A., J. Walsh, J. Watterson, and P. Bretan (1995). "Three-dimensional geometry and growth of conjugate normal faults". Journal of Structural Geology 17.6, pp. 847-862. DOI: 10.1016/0191-8141 (94) 00109-d.

Nicol, A., J. Watterson, J. Walsh, and C. Childs (1996). "The shapes, major axis orientations and displacement patterns of fault surfaces". Journal of Structural Geology 18.2-3, pp. 235-248. DoI: 10.1016 / s0191 $8141(96) 80047-2$.

Oehlers, D. J., H. D. Wright, and M. J. Burnet (1994). "Flexural Strength of Profiled Beams". Journal of Structural Engineering 120.2, pp. 378-393. DOI: 10 . 1061/(asce) 0733-9445(1994) 120:2 (378).

Paganoni, M., J. J. King, M. Foschi, K. Mellor-Jones, and J. A. Cartwright (2019). "A natural gas hydrate system on the Exmouth Plateau (NW shelf of Australia) sourced by thermogenic hydrocarbon leakage". Marine and Petroleum Geology 99, pp. 370-392. Dor: 10 . 1016/j . marpetgeo.2018.10.029.

Paumard, V., J. Bourget, T. Payenberg, R. B. Ainsworth, A. D. George, S. Lang, H. W. Posamentier, and D. Peyrot (2018). "Controls on shelf-margin architecture and sediment partitioning during a syn-rift to post-rift transition: Insights from the Barrow Group (Northern Carnarvon Basin, North West Shelf, Australia)". Earth-Science Reviews 177, pp. 643-677. DoI: 10.1016/j . earscirev.2017.11.026.

Peacock, D. and D. Sanderson (1991). "Displacements, segment linkage and relay ramps in normal fault zones". Journal of Structural Geology 13.6, pp. 721733. DoI: 10.1016/0191-8141(91)90033-f.

Planke, S., T. Rasmussen, S. S. Rey, and R. Myklebust (2005). "Seismic characteristics and distribution of volcanic intrusions and hydrothermal vent complexes in the Vøring and Møre basins". Geological Society, London, Petroleum Geology Conference series 6.1, pp. 833-844. DoI: 10.1144/0060833.
Pollard, D. D. and A. M. Johnson (1973). "Mechanics of growth of some laccolithic intrusions in the Henry mountains, Utah, II". Tectonophysics 18.3-4, pp. 311354. DoI: $10.1016 / 0040-1951$ (73)90051-6.

Polteau, S., A. Mazzini, O. Galland, S. Planke, and A. Malthe-Sørenssen (2008). "Saucer-shaped intrusions: Occurrences, emplacement and implications". Earth and Planetary Science Letters 266.1-2, pp. 195-204. Dor: $10.1016 /$ j.epsl.2007.11.015.

Poppe, S., E. P. Holohan, O. Galland, N. Buls, G. V. Gompel, B. Keelson, P.-Y. Tournigand, J. Brancart, D. Hollis, A. Nila, and M. Kervyn (2019). "An Inside Perspective on Magma Intrusion: Quantifying 3D Displacement and Strain in Laboratory Experiments by Dynamic X-Ray Computed Tomography". Frontiers in Earth Science 7. DoI: 10.3389/feart.2019.00062.

Pritchard, M. E. and M. Simons (2004). "An InSARbased survey of volcanic deformation in the central Andes". Geochemistry, Geophysics, Geosystems 5.2. DOI: $10.1029 / 2003 \mathrm{gc} 000610$.

Pryer, L., K. Romine, T. Loutit, and R. Barnes (2002). "Carnarvon basin architecture and structure defined by the integration of mineral and petroleum exploration tools and techniques". The APPEA Journal 42.1, p. 287. DOI: $10.1071 / \mathrm{aj} 01016$.

Reeve, M. T. (2017). "The structural and stratigraphic expression of continental breakup". PhD thesis. Imperial College London, UK.

Reeve, M. T., C. A.-L. Jackson, R. E. Bell, C. Magee, and I. D. Bastow (2016). "The stratigraphic record of prebreakup geodynamics: Evidence from the Barrow Delta, offshore Northwest Australia". Tectonics 35.8, pp. 1935-1968. DoI: 10.1002/2016tc004172.

Reeves, J., C. Magee, and C. A.-L. Jackson (2018). "Unravelling intrusion-induced forced fold kinematics and ground deformation using 3D seismic reflection data". Volcanica, pp. 1-17. Dor: 10.30909/vol.01.01. 0117.

Reilly, C., A. Nicol, J. J. Walsh, and H. Seebeck (2015). "Evolution of faulting and plate boundary deformation in the Southern Taranaki Basin, New Zealand". Tectonophysics 651-652, pp. 1-18. DoI: $10.1016 / \mathrm{j}$. tecto.2015.02.009.

Rey, S. S., S. Planke, P. A. Symonds, and J. I. Faleide (2008). "Seismic volcanostratigraphy of the Gascoyne margin, Western Australia". Journal of Volcanology and Geothermal Research 172.1-2, pp. 112-131. DoI: 10.1016/j.jvolgeores.2006.11.013.

Robb, M. S., B. Taylor, and A. M. Goodliffe (2005). "Reexamination of the magnetic lineations of the Gascoyne and Cuvier Abyssal Plains, off NW Australia". Geophysical Journal International 163.1, pp. 42-55. DoI: $10.1111 / \mathrm{j} .1365-246 \mathrm{x} .2005 .02727 . \mathrm{x}$.

Robson, A. G., R. C. King, and S. P. Holford (2016). "Structural evolution of a gravitationally detached normal fault array: analysis of 3D seismic data from the Ceduna Sub-Basin, Great Australian Bight". Basin Research 29.5, pp. 605-624. Dor: 10.1111/bre. 12191. 
Rohrman, M. (2013). "Intrusive large igneous provinces below sedimentary basins: An example from the Exmouth Plateau (NW Australia)". Journal of Geophysical Research: Solid Earth 118.8, pp. 44774487. DoI: 10.1002 /jgrb. 50298 .

- (2015). "Delineating the Exmouth mantle plume (NW Australia) from denudation and magmatic addition estimates". Lithosphere 7.5, pp. 589-600. Dor: $10.1130 / 1445.1$.

Rotevatn, A., C. A.-L. Jackson, A. B. Tvedt, R. E. Bell, and I. Blækkan (2019). "How do normal faults grow?" Journal of Structural Geology 125, pp. 174184. DoI: $10.1016 / \mathrm{j}$.jsg.2018.08.005.

Schmiedel, T., O. Galland, Ø. Haug, G. Dumazer, and C. Breitkreuz (2019). "Coulomb failure of Earth's brittle crust controls growth, emplacement and shapes of igneous sills, saucer-shaped sills and laccoliths". Earth and Planetary Science Letters 510, pp. 161-172. Dor: 10.1016/j.epsl.2019.01.011.

Schmiedel, T., S. Kjoberg, S. Planke, C. Magee, O. Galland, N. Schofield, C. A.-L. Jackson, and D. A. Jerram (2017). "Mechanisms of overburden deformation associated with the emplacement of the Tulipan sill, mid-Norwegian margin". Interpretation 5.3, SK23SK38. DoI: 10.1190/int-2016-0155.1.

Schofield, N. J., D. J. Brown, C. Magee, and C. T. Stevenson (2012). "Sill morphology and comparison of brittle and non-brittle emplacement mechanisms". Journal of the Geological Society 169.2, pp. 127-141. DoI: 10.1144/0016-76492011-078.

Schofield, N. et al. (2017). "Regional magma plumbing and emplacement mechanisms of the Faroe-Shetland Sill Complex: implications for magma transport and petroleum systems within sedimentary basins". Basin Research 29.1, pp. 41-63. Dor: $10.1111 /$ bre . 12164.

Sclater, J. G. and P. A. F. Christie (1980). "Continental stretching: An explanation of the PostMid-Cretaceous subsidence of the central North Sea Basin". Journal of Geophysical Research: Solid Earth 85.B7, pp. 3711-3739. DOI: 10 . $1029 /$ jb085ib07p03711.

Sigmundsson, F. et al. (2020). "Unexpected large eruptions from buoyant magma bodies within viscoelastic crust". Nature Communications 11.1. DoI: 10.1038/ s41467-020-16054-6.

Siregar, E., K. Omosanya, C. Magee, and S. E. Johansen (2019). "Impacts of fault-sill interactions on sill emplacement in the Vøring Basin, Norwegian North Sea". Journal of Structural Geology 126, pp. 156-174. Dor: $10.1016 / j . j s g .2019 .06 .006$.

Skogly, O. (1998). "Seismic characterization and emplacement of intrusives in the Vøring Basin". MA thesis. University of Oslo.

Smallwood, J. R. and J. Maresh (2002). "The properties, morphology and distribution of igneous sills: modelling, borehole data and 3D seismic from the Faroe-Shetland area". Geological Society, London, Spe- cial Publications 197.1, pp. 271-306. Dor: 10.1144/ gsl.sp.2002.197.01.11.

Sparks, R. S. J., J. Biggs, and J. W. Neuberg (2012). "Monitoring Volcanoes". Science 335.6074, pp. 13101311. DoI: 10.1126 /science. 1219485.

Stagg, H., M. Alcock, G. Bernardel, A. Moore, P. Symonds, and N. Exon (2004). Geological framework of the outer Exmouth Plateau and adjacent ocean basins. Geoscience Australia.

Stearns, D. W. (1978). "Faulting and forced folding in the Rocky Mountains foreland". Geological Society of America Memoirs. Geological Society of America, pp. 1-38. DoI: 10.1130/mem151-p1.

Symonds, P. A., S. Planke, O. Frey, and J. Skogseid (1998). "Volcanic evolution of the Western Australian Continental Margin and its implications for basin development". The Sedimentary Basins of Western Australia. Ed. by P. G. Purrcell and R. R. Purcell. Vol. 2. The Petroleum Exploration Society of Australia.

Thomson, K. and D. Hutton (2004). "Geometry and growth of sill complexes: insights using 3D seismic from the North Rockall Trough". Bulletin of Volcanology 66.4, pp. 364-375. Dor: 10.1007 / s00445-0030320-z.

Thomson, K. and N. Schofield (2008). "Lithological and structural controls on the emplacement and morphology of sills in sedimentary basins". Geological Society, London, Special Publications 302.1, pp. 31-44. DOI: $10.1144 / \mathrm{sp} 302.3$.

Thorsen, C. E. (1963). "Age of growth faulting in southeast Louisiana". Gulf Coast Association of Geological Societies Transactions 13, pp. 103-110.

Tindale, K., N. Newell, J. Keall, and N. Smith (1998). "Structural evolution and charge history of the Exmouth Sub-basin, northern Carnarvon Basin, Western Australia". The Sedimentary Basins of Western Australia. Ed. by P. G. Purrcell and R. R. Purcell. Vol. 2. The Petroleum Exploration Society of Australia.

Trude, J., J. Cartwright, R. J. Davies, and J. Smallwood (2003). "New technique for dating igneous sills". Geology 31.9, p. 813. DoI: 10.1130/g19559.1.

Trudgill, B. and J. Cartwright (1994). "Relay-ramp forms and normal-fault linkages, Canyonlands National Park, Utah". Geological Society of America Bulletin 106.9, pp. 1143-1157. DoI: $10.1130 / 0016$ 7606 (1994) $106<1143: \operatorname{rrfanf}>2.3$. co; 2 .

Tvedt, A. B., A. Rotevatn, C. A.-L. Jackson, H. Fossen, and R. L. Gawthorpe (2013). "Growth of normal faults in multilayer sequences: A 3D seismic case study from the Egersund Basin, Norwegian North Sea". Journal of Structural Geology 55, pp. 1-20. Dor: 10.1016/j.jsg.2013.08.002.

Valentine, G. and K. Krogh (2006). "Emplacement of shallow dikes and sills beneath a small basaltic volcanic center-The role of pre-existing structure (Paiute Ridge, southern Nevada, USA)". Earth and Planetary Science Letters 246.3-4, pp. 217-230. DOI: 10.1016/j.epsl.2006.04.031. 
Van Wyk de Vries, B., A. Márquez, R. Herrera, J. L. G. Bruña, P. Llanes, and A. Delcamp (2014). "Craters of elevation revisited: forced-folds, bulging and uplift of volcanoes". Bulletin of Volcanology 76.11. Dor: 10 . $1007 / \mathrm{s} 00445-014-0875-\mathrm{x}$.

Velayatham, T., S. Holford, M. Bunch, R. King, and C. Magee (2019). "3D Seismic Analysis of Ancient Subsurface Fluid Flow in the Exmouth Plateau, Offshore Western Australia". The Sedimentary Basins of Western Australia V. Ed. by M. Keep and S. J. Moss. Vol. 5. The Petroleum Exploration Society of Australia.

Walsh, J. J., W. R. Bailey, C. Childs, A. Nicol, and C. G. Bonson (2003). "Formation of segmented normal faults: a 3-D perspective". Journal of Structural Geology 25.8, pp. 1251-1262. DOI: $10.1016 /$ s 0191 $8141(02) 00161-\mathrm{x}$.

Walsh, J. J. and J. Watterson (1989). "Displacement gradients on fault surfaces". Journal of Structural Geology 11.3, pp. 307-316. DoI: 10.1016/0191-8141(89) 90070-9.
Walsh, J. J. and J. Watterson (1988). "Analysis of the relationship between displacements and dimensions of faults". Journal of Structural Geology 10.3, pp. 239247. DOI: 10.1016/0191-8141(88)90057-0.

Watterson, J. (1986). "Fault dimensions, displacements and growth". Pure and Applied Geophysics 124.1-2, pp. 365-373. Dor: 10.1007/bf00875732.

Wilson, P. I., K. J. McCaffrey, R. W. Wilson, I. Jarvis, and R. E. Holdsworth (2016). "Deformation structures associated with the Trachyte Mesa intrusion, Henry Mountains, Utah: Implications for sill and laccolith emplacement mechanisms". Journal of Structural Geology 87, pp. 30-46. Dor: $10.1016 / \mathrm{j} \cdot \mathrm{j}$ sg . 2016 . 04 . 001.

Yang, X.-M. and C. Elders (2016). "The Mesozoic structural evolution of the Gorgon Platform, North Carnarvon Basin, Australia". Australian Journal of Earth Sciences 63.6, pp. 755-770. DoI: $10.1080 /$ 08120099.2016 .1243579 . 